\title{
Risk-Taking Spillovers of U.S. Monetary Policy in the Global Markets for U.S. Dollar Corporate Loans
}

Lee, Seung Jung, Lucy Qian Liu, and Viktors Stebunovs

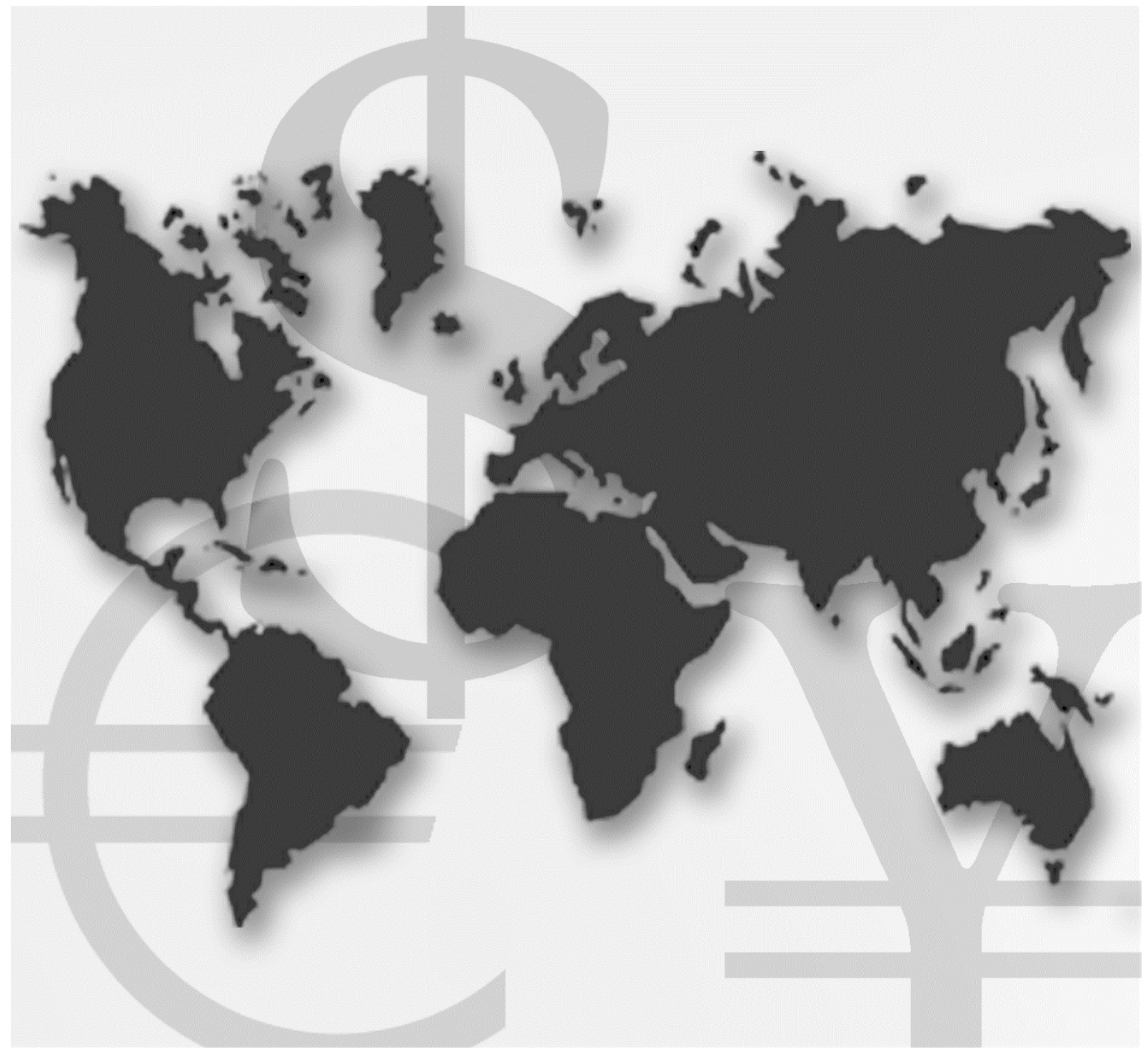

\section{International Finance Discussion Papers}

Board of Governors of the Federal Reserve System 
Board of Governors of the Federal Reserve System

International Finance Discussion Papers

Number 1251

June 2019

\title{
Risk-Taking Spillovers of U.S. Monetary Policy in the Global Market for U.S. Dollar Corporate Loans
}

\author{
Seung Jung Lee, Lucy Qian Liu, and Viktors Stebunovs
}

NOTE: International Finance Discussion Papers are preliminary materials circulated to stimulate discussion and critical comment. References to International Finance Discussion Papers (other than an acknowledgment that the writer has had access to unpublished material) should be cleared with the author or authors. Recent IFDPs are available on the Web at www.federalreserve.gov/pubs/ifdp/. This paper can be downloaded without charge from the Social Science Research Network electronic library at www.ssrn.com. 


\title{
Risk-Taking Spillovers of U.S. Monetary Policy in the Global Market for U.S. Dollar Corporate Loans
}

\author{
Seung Jung Lee\# \\ Lucy Qian Liu ${ }^{\dagger}$ \\ Viktors Stebunovs
}

Abstract: We study the effects of U.S. interest rates and other factors on risk-taking in the global market for U.S. dollar syndicated term loans. We find that, before the Global Financial Crisis, both U.S. and non-U.S. lenders originated ex ante riskier loans to non-U.S. borrowers in response to a decline in short-term U.S. interest rates and, after the crisis, in response to a decline in longer-term U.S. interest rates. After the crisis, this behavior was more prominent for shadow banks and less prominent for banks with relatively low capital. Separately, before the crisis, lenders originated less risky loans in response to U.S. dollar appreciation. Across the periods, the responses to risk appetite and economic uncertainty varied. To the extent that the Federal Reserve affects U.S. interest rates, we provide evidence of global risk-taking spillovers of U.S. monetary policy, which are important but not dominant factors for risk-taking in the market.

Keywords: Syndicated leveraged loans, risk-taking, global factors, U.S. monetary policy, global spillovers.

JEL Classifications: E44, E52, F30, F42, G15, G20.

\# Board of Governors of the Federal Reserve System, 20th Street and Constitution Avenue, NW, Washington, DC 20551, U.S.A.; seung.j.lee@frb.gov. URL: ` International Monetary Fund, 700 19th Street, NW, Washington, DC 20431, U.S.A.; qliu3@imf.org.

$\ddagger$ Board of Governors of the Federal Reserve System, 20th Street and Constitution Avenue, NW, Washington, DC 20551, U.S.A.; viktors.stebunovs@frb.gov. URL: We thank Geert Bekaert (the editor) and two anonymous referees for valuable comments. We also thank Mark Carey, Stijn Claessens, and Karlye Dilts Stedman (discussant) for helpful feedback and Juan M. Londono for help with variance risk premium data. The views in this paper are solely the responsibility of the authors and should not be interpreted as reflecting the views of the Board of Governors of the Federal Reserve System or the Federal Reserve System and the International Monetary Fund, its Executive Board, or its management. 


\section{Introduction}

In the aftermath of the Global Financial Crisis (GFC), historically very low interest rates set by central banks in significant advanced economies have sparked a debate about global spillovers of such policies. In turn, we examine the effects of U.S. interest rates and other factors, such as risk aversion and the U.S. dollar exchange rate, on risk-taking by various types of lenders in the global primary market for U.S. dollar syndicated term loans - a large market for risky cross-border corporate term loans. Specifically, we study whether low U.S. interest rates induced lenders around the globe to originate ex ante riskier loans to non-U.S. borrowers and whether this behavior was more prominent for lenders of certain characteristics. We differentiate responses of risk-taking to short- and longer-term U.S. interest rates before and after the GFC. To the extent that actions of the Federal Reserve affect these interest rates, we provide evidence of a global risk-taking channel of U.S. monetary policy and document its economic significance relative to that of the other factors.

The global primary market for U.S. dollar syndicated term loans is a suitable venue to study these issues for several reasons. First, this market is comparable in terms of size to the global primary market for U.S. dollar corporate bonds. Second, the vast majority of syndicated term loans are made to speculative-grade and obscure, non-rated corporations, so lenders take on large positions in risky, mostly leveraged loans. Third, a significant portion of non-U.S. borrowers in the market is from emerging markets, which allows us to identify more robustly any cross-border effects of global factors. Fourth, while banks tend to originate the majority of syndicated term loans, they sell shares in these loans within one month from origination to shadow banks. Hence, the riskiness of loans being originated reflects, to a large extent, risk-taking behavior of the broader financial system rather than just banks. Finally, this market has been tracked for a few decades by data vendors that compile vast, detailed loan-level data sets.

We use one such loan-level data set-Refinitiv Loan Pricing Corporation (LPC) DealScan — and focus on cross-border term loans made by U.S. and non-U.S. lenders to non-U.S. borrowers over nearly two decades. Because of the richness of the data, we can differentiate borrowers and lenders by their industry too. One limitation of the data set is that it does not provide ex ante credit risk measures. Our workaround is to construct projections of probabilities of borrower default using Moody's Analytics CreditEdge expected default frequencies (EDFs) 1 To identify the effects of U.S. monetary policy and the other factors on risk-taking in the global syndicated loan market, we exclude U.S. borrowers from all regressions and U.S. lenders from many regressions and focus on loan originations by lenders to borrowers from dozens of less significant advanced economies and emerging markets. In a way, we mimic the strategy of Jimenez, Ongena, Peydro, and Saurina (2014), who study Spanish banks' risk-taking in response to euro-area interest rates, and that of Ioannidou, Ongena, and Peydro (2015), who examine Bolivian banks' risk-taking in response to U.S. interest rates. In both papers, monetary policy is deemed to be exogenous to the country.

We find robust evidence that lenders of various types and nationalities originated ex ante riskier loans to non-U.S. borrowers in response to lower U.S. interest rates - short-term rates before the

\footnotetext{
${ }^{1}$ In contrast to Altunbas, Gambacorta, and Marques-Ibanez (2014), we study the effects of monetary policy on probabilities of default of borrowers rather than of lenders.
} 
GFC and longer-term rates after it ${ }^{2}$ As for the results by lender characteristics, we find that this behavior in the post-crisis period was more prominent for shadow banks and less prominent for banks with relatively low capital. Given that the Federal Reserve explicitly targeted the federal funds rate before the crisis and implicitly targeted longer-term U.S. Treasury rates after it, we present evidence of a global risk-taking channel of U.S. monetary policy. Our findings suggest that informational frictions and limited liability are not necessary ingredients for risk-taking by financial intermediaries in the market.

We acknowledge that one cannot contribute all the movement in longer-term U.S. interest rates to the Federal Reserve's actions in the post-crisis period. While Krishnamurthy and VissingJorgensen (2011), D'Amico, English, López-Salido, and Nelson (2012), and D'Amico and King (2013) find that the Federal Reserve's unconventional monetary policies indeed reduced interest rates on longer-term U.S. Treasury securities, some international developments likely exerted additional downward pressure. For instance, following the European sovereign crisis, amid higher uncertainty and risk aversion, safe haven inflows to safe U.S. assets put additional downward pressures on longer-term U.S. interest rates. To control for such developments, we include a euro-area sovereign spread and the decomposition of the VIX index into "risk aversion" and "uncertainty" components (as in Bekaert, Hoerova, and Lo Duca (2013), Bekaert and Hoerova (2014), and Londono (2011)) in our regressions. For completeness, we include the economic uncertainty index of Baker, Bloom, and Davis (2016).

We estimate that the marginal effects of U.S. interest rates on risk-taking are comparable to those of the other statistically significant factors. Typically, a change of one standard deviation in a global factor resulted in a change of a couple of dozen basis points in probabilities of default of loans being originated. We also document that, in terms of marginal effects, the effects of U.S. monetary policy were stronger for lenders that specialize in particularly risky loans. Similarly, the spillovers of U.S. monetary policy on risk-taking were stronger for lending to borrowers in emerging markets than for lending to borrowers in advanced economies. Overall, we conclude that global risk-taking spillovers of U.S. monetary policy are important but not dominant factors for risk-taking in the market.

We build on the literature on global push and local pull factors that affect risk-taking in the global financial system, which relies on aggregate data. Among global push factors, the literature includes U.S. monetary policy. For example, Bruno and Shin (2015) find that an expansionary shock to U.S. monetary policy leads to an increase in cross-border bank flows and in the leverage of international banks, and then a depreciation of the U.S dollar. Other global push factors include uncertainty and risk aversion. For example, Rey (2015) concludes that there is a potent global financial cycle in capital flows, credit creation and asset prices, which has tight connections with changes in uncertainty and risk aversion, proxied by the VIX index. This literature typically does not examine ex ante credit risk of cross-border flows and, arguably, the credit risk of flows - not just their magnitude - matters for financial stability. Indeed, Kalemli-Ozcan, Sorensen, and Yesiltas (2012) argue that quantitative measures of risky assets may not be sufficient to detect financial

\footnotetext{
${ }^{2}$ Of note, the post-crisis results are implicitly conditional on short-term U.S. interest rates being at the zero lower bound.
} 
vulnerability, as risk-taking involves the quality rather than quantity of assets. Their findings imply that studying ex ante credit risk in disaggregate data is a promising direction - the direction that we follow in this paper.

We also build on the literature on the domestic risk-taking channel of monetary policy, which studies short-term interest rates as factors and banks as conduits 3 The theoretical strand focuses on the relationship between short-term interest rates and risk-taking in the presence of asymmetric information and limited liability - for example, Dell'Ariccia, Laeven, and Marquez (2014). The empirical strand follows the same direction. For instance, Dell'Ariccia, Laeven, and Suarez (2017) use U.S. data on banks' internal ratings of small loans to businesses to show that banks' ex ante risk-taking is negatively associated with short-term interest rates, with a weaker association for banks with relatively low capital. In turn, Aramonte, Lee, and Stebunovs (2019) find that, in the United States, various types of financial intermediaries - in particular investment funds and CLOs - originated or invested in ex ante riskier syndicated term loans in response to lower expected short-term and spot and forward long-term interest rates. Their findings suggest that the presence of frictions is not a necessary condition for financial intermediaries to take on higher ex ante credit risk as interest rates decline. Indeed, the portfolio allocation theory (as in Fishburn and Porter (1976) - which is applicable to a variety of types of financial intermediaries - predicts that, under some mild assumptions about investor risk aversion, the optimal proportion invested in risky assets will increase with a decrease in returns on safe assets. In turn, we examine the effects of both shortand longer-term interest rates on ex ante risk-taking by both banks and shadow banks.

We also draw on the literature on the international risk-taking channel of monetary policy, which considers the effects of monetary policy in one country on risk-taking in another country. For example, Ioannidou, Ongena, and Peydro (2015) find that as short-term U.S. interest rates declined banks in Bolivia originated ex ante riskier loans but did not price this additional risk adequately. In the same vein, Morais, Peydro, Roldan-Pena, and Ruiz-Ortega (2019) show that foreign banks in Mexico increased risk-taking with easings in foreign monetary policies. Furthermore, Jimenez, Ongena, Peydro, and Saurina (2014) show that banks in Spain took more credit risk as short-term euro-area interest rates declined. In turn, we study a global risk-taking channel of U.S. monetary policy: We capture the risk-taking spillovers of U.S. monetary policy in the global market for U.S. dollar syndicated term loans where financial intermediaries of various types and nationalities and corporate borrowers of various nationalities meet.

We rely to a lesser extent on the literature on transmission of monetary policy through volumes of cross-border lending by internationally-active financial intermediaries in advanced economiesfor example, Temesvary, Ongena, and Owen (2018) and Argimon, Bonner, Correa, Duijm, Frost, de Haan, de Haan, and Stebunovs (2019) - and the role of bank-internal capital and liquidity markets in such transmission-Cetorelli and Goldberg (2012) and Correa, Goldberg, and Rice (2015).

The reminder of the paper is organized as follows. Section 2 describes key features of loan syndication and the global market for U.S dollar, Libor-indexed syndicated loans. Section 3 presents

\footnotetext{
${ }^{3}$ That said, some papers study risk-taking by U.S. financial intermediaries other than banks - for example, Chodorow-Reich (2014) and Di Maggio and Kacperczyk (2017).
} 
the empirical methodology that we use to examine the relationship between originations of ex ante riskier loans in the market and U.S. interest rates and other factors. Section 4 summarizes the estimation results and discusses caveats and robustness checks. Section 5 concludes with a few remarks on the implications of our findings for financial stability issues. We define shadow banks as financial intermediaries that are not banks and such and we use the terms "shadow banks" and "nonbanks" and "nonbank lenders" interchangeably.

\section{Loan syndication}

In this section, we provide some background information on the loan syndication process, the global market for U.S dollar, Libor-indexed syndicated loans, and a particular segment of this market. One of the advantages of studying the global syndicated loan market is its wide coverage of lenders of various types and nationalities that supply credit to borrowers of varying credit quality from around the world.

We focus on syndicated term loans. A syndicated term loan is different from a bilateral bank term loan or a corporate bond. In contrast to a bilateral bank term loan, a syndicated term loan is extended to a borrower by multiple lenders, that are not necessarily banks, that form a syndicate for that purpose, and it is administered by an agent, typically a bank. In contrast to a corporate bond, a syndicated term loan's interest rate is floating: It is equal to a contractuallyfixed loan spread over a benchmark interest rate. Therefore, for a given syndicated term loan, the interest rate changes with the benchmark interest rate, minimizing lenders' interest rate risk. The loan spread is determined at origination, reflects lenders' judgments about the loan's credit risk, and stays constant over the loan's duration unless the financial conditions of the borrower change substantially and the loan covenants require a subsequent loan repricing. Syndicated term loans are dispersed at origination and usually have a maturity of five to seven years, which is shorter than that of corporate bonds.

Besides syndicated term loans, lenders also originate syndicated credit lines, but we exclude those loans from the analysis for two reasons. First, while a variety of different types of lenders originate and hold term loans, the lenders of credit lines are predominantly banks (see Aramonte, Lee, and Stebunovs (2019)). Given the increasing importance of shadow banks in the market, we aim to keep the analysis broad. Second, because borrowers draw down credit lines at will, these lines have more complex pricing than term loans and their originations and drawdowns are more endogenous to the credit and business cycles 4

While lenders originate loans in the global syndicated loan market in various currencies with various benchmark rates, we focus on term loans that are denominated in U.S. dollars and indexed to the U.S. dollar Libor. Such U.S. dollar loans dominate the market by a large margin. Between the late 1990s and 2007, originations of such loans rose at a fast pace and then subsequently collapsed with the GFC. Since reaching a trough in 2009, loan originations recovered substantially

\footnotetext{
${ }^{4}$ For potential endogeneity, Ivashina and Scharfstein (2010a) document that, during the U.S. financial crisis of 2008, large firms drew on credit lines because of, in part, uncertainty in the financial sector.
} 
and reached about $\$ 1.3$ trillion in 2013. (These estimates are based on the Refinitiv Loan Pricing Corporation (LPC) DealScan data.)

We analyze a particular segment of the market - loan originations to non-U.S. borrowers, which totaled about $\$ 300$ billion in 2013. In terms of risk profile, the vast majority of syndicated term loans in the segment are extended to risky, opaque borrowers. As illustrated in the left panel in figure 1, loans to nonrated borrowers dominated originations, whereas loans to investment-grade and speculative-grade borrowers accounted for only modest to moderate fractions. Loans extended to nonrated and speculative-grade borrowers tend to be leveraged. In terms of geographical composition, loans extended to borrowers from emerging markets accounted for a sizable share of the segment's originations, as shown in the right panel in figure 1 .

Banks and their holding companies - banks, for short-accounted for about 80 percent of originations volume globally, and the rest was originated by nonbank lenders. Moreover, among banks, originations were dominated by a group of select lenders. The dominance of banks at origination and the potential for the originate-to-distribute model are not surprising: Banks have larger pools of potential borrowers and loan investors and a stronger capacity to evaluate the credit risk of borrowers than nonbanks - a dominant class of loan investors - have.

Banks originate syndicated loans with the intent to distribute to shadow banks that either precommit to buy shares in the loans being originated or buy those shares shortly after the origination directly from the originators or in the secondary market. Indeed, bank-owned shares in seasoned syndicated term loans tend to be much lower than those at origination. According to the U.S. confidential supervisory Shared National Credit (SNC) data on syndicated lending by U.S. banks (to both U.S. and non-U.S. borrowers), banks own only over a third of all term loans, nonbanks such as investment funds, structured finance products, portfolio managers, finance companies, and other types account for the rest. From this perspective, nonbanks are well-represented in the syndicated term loan market even though their share at origination is not that large. Of note, nonbanks acquire shares in loans very quickly as shown in figure 2, which plots a sequence of box plots of bank-owned shares in loans since origination. The figure suggests that the median of bank-owned shares in loans declines from about 90 percent to about 20 percent within a few weeks after loan origination 5

\section{Empirical methodology}

In this section, we detail our empirical methodology. First, we cover briefly the specifics of our source for syndicated term loan data. Second, we discuss the choice and construction of our loan-level ex ante credit risk measure. Third, we describe the setup of loan- and portfolio level regressions that identify risk-taking spillovers of U.S. monetary policy.

\footnotetext{
${ }^{5}$ The figure is based on the SNC data for a relative short period-from 2009:Q4 to 2013:Q4. We allow that the speed of the sales varies with the credit and business cycles. See Ivashina and Scharfstein (2010b) for a related discussion.
} 


\subsection{Syndicated term loan data}

For our analysis, we draw syndicated loan data from Refinitiv Loan Pricing Corporation (LPC) DealScan. This data set contains detailed information on syndicated loans, including names, industries, locations of borrowers and lenders, and compositions of the syndicates at loan origination. We analyze lending on an ultimate counterparty basis. Specifically, we aggregate lenders up to their parent organizations - to ultimate lenders. The approach reflects the notion that risk management in financial institutions is carried out at a parent-company level. We also distinguish lenders and borrowers by their types. We rely on two-digit SIC codes for primary activity given in the DealScan data to classify lenders. For borrowers, we rely on the Fama-French industry classifications based on SIC codes to identify primary industries of borrowers (Fama and French (1997)). We exclude from the analysis the GFC period (2007:Q3 to 2009:Q2) because it would be difficult to disentangle the relationship between interest rates and risk-taking with extreme market turbulence, such as the shutdown in short-term wholesale funding markets, heightened regulatory and supervisory scrutiny, and a spike in volatility in asset markets.

\subsection{Measure of ex ante credit risk}

We have limited options for ex ante credit risk measures. Because our syndicated loan data set does not provide such measures, we cannot follow the approach of Dell'Ariccia, Laeven, and Suarez (2017) which relies on internal bank ratings of credit quality of new loans or the approach of Aramonte, Lee, and Stebunovs (2019) which uses banks' estimates of probabilities of loan default. One workaround is to rely on loan spreads as a comprehensive proxy for ex ante credit risk and other credit risk-related factors as in Lee, Liu, and Stebunovs (2017). That paper and Aramonte, Lee, and Stebunovs (2019) show that variation in banks' estimates of probabilities of loan default account for 40 to 50 percent in variation of loan spreads and a few more credit-risk related loan characteristics account for a further 10 percent. A drawback of this approach is that loan spreads incorporate not only objective risk characteristics but also risk premiums. That said, these papers suggest that risk premiums likely play a small role as risk appetite and economic uncertainty explain only a small fraction of variation in loan spreads. Another issue is that loan spreads on loans of the same observable credit risk may vary significantly across regions. For example, Carey and Nini (2007) show that loan spreads on syndicated loans to corporate borrowers are economically significantly smaller in Europe than in the United States, other things equal.

The workaround that we use is largely immune to risk premium concerns. We construct projections of probabilities of default - often-used ex ante credit risk measures - for loans in the sample based on historical relationships between these measures and loan and borrower characteristics in subsamples ${ }^{6}$

We take the following steps to construct these projections. We focus on Moody's Analytics

\footnotetext{
${ }^{6}$ We dismissed using debt ratings of borrowers because they are very crude measures of ex ante credit risk and because the majority of borrowers do not have debt ratings. Separately, lender-own assessments of probability of borrower default may differ from EDFs. Indeed, Aramonte, Lee, and Stebunovs (2019) show that EDFs tend to be lower than lender-own assessments.
} 
CreditEdge EDFs - forward-looking annualized probabilities of default at various horizons - as objective measures of borrower ex ante credit risk. These EDFs are based on the structural debt pricing model of Merton (1974) and historical global corporate default data. We use the most recent vintage of the EDF data that incorporates information from the GFC and post-GFC periods 7 We then merge the EDF data and the Refinitiv LPC DealScan data by borrower names and other details using the matching algorithm in Cohen, Friedrichs, Gupta, Hayes, Lee, Marsh, Mislang, Shaton, and Sicilian (2018). We match borrower EDFs to about 790 syndicated loans in the pre-crisis period (13 percent of syndicated loans) and about 430 syndicated loans in the post-crisis period (23 percent of syndicated loans). Because the merge matches only a moderate percentage of DealScan loans with CreditEdge EDFs, we estimate on the matched sample an equation that maps loan and borrower characteristics into EDFs. Of note, for a given loan-borrower EDF match, we retain an EDF for a horizon that approximates the maturity of the loan. We then use the estimated model to project EDFs conditional on loan and borrower characteristics for the unmatched loans.

We have strong reasons to project EDFs conditional on loan characteristics in addition to borrower characteristics. As Strahan (1999) shows, both the price and non-price terms of syndicated loans reflect credit risk of borrowers. As expected, the price and non-price terms of loans reflect observable components of borrower risk: Riskier borrowers-borrowers that are smaller and have less cash and borrowers that are harder for outside investors to value-pay more for their loans. Moreover, the non-price terms of loans - such as loan size, loan maturity, and collateral requirement - explain, conditional on observable measures of credit risk, loan spreads. We, thus, conclude that non-price terms may reveal credit risk concerns beyond those that are observable. Separately, the literature - for example, Aramonte, Lee, and Stebunovs $(2019)$ — shows that shadow banks tend to invest in riskier loans (so-called institutional loans). To sum up, the literature makes a convincing case that one can deduce ex ante credit risk of a loan given its characteristics.

We estimate the following equation that maps loan and borrower characteristics into loan EDFs:

$$
\log \left(E D F_{j, b, t}\right)=\mathbf{X}_{j, t} \beta+\mathbf{Z}_{j, t} \eta+\rho_{b, t}+\delta_{c}+\gamma_{i}+\theta_{t}+\varepsilon_{j, b, t}
$$

where $E D F_{j, b, t}$ is the EDF for loan $j$ to borrower $b$ in country $c$ and industry $i$ at time $t . \mathbf{X}_{j, t}$ is a vector of select continuous loan characteristics (logs of loan spread, loan amount, and loan maturity). $\mathbf{Z}_{j, t}$ is a vector of binary loan characteristics (secured loan, loan purpose, and loan type) and of syndicate characteristics (number of lenders and presence of shadow banks among the lenders). $\rho_{b, t}$ is a fixed effect for a credit rating of borrower $b$ 's senior debt at loan origination (investment grade, speculative grade, nonrated). $\delta_{c}$ is a borrower country fixed effect, $\gamma_{i}$ is a borrower industry fixed effect (Fama and French's 38 industries), and $\theta_{t}$ is a fixed effect for the quarter of loan $j$ 's origination (first, second, and so on). $\varepsilon_{j, b, t}$ is a white noise error. We estimate the equation separately for the pre- and post-crisis periods to account for potential structural breaks in regression coefficients, including those in fixed effects. In an alternative specification, we include time fixed effects; the inclusion of such effects, many of which are statistically insignificant, does not have notable quantitative effects. By the virtue of the mapping equation, we use the terms

\footnotetext{
${ }^{7}$ See Nazeran and Dwyer (2015) for a detailed description of the modeling methodology.
} 
"borrower EDFs" and "loan EDFs" interchangeably.

We control for the quarter of loan origination to account for the seasonality in loan pricing and originations. As Murfin and Petersen (2016) suggest, the market for syndicated loans has significant seasonal variation, with borrowers in winter and summer paying higher loan spreads than borrowers in fall and spring. They argue that firms with unanticipated, non-deferrable investment needs tend to borrow in high loan spread seasons. We think that this urgency to borrow in a high-spread period may also reflect borrowers' tighter financial constraints and lower credit quality.

\subsection{Risk-taking spillovers of U.S. monetary policy}

We rely on the richness of our panel data to identify risk-taking spillovers of U.S. monetary policy. We posit that each lender takes short- and longer-term U.S. interest rates and other factors as given and makes their risk-taking decisions in response to these factors. In particular, we associate short-term U.S. rates with the cost of short-term U.S. dollar funding and interest rates on longer-term U.S. Treasury securities with returns on safe U.S. dollar assets. Put differently, we focus on two risk-taking channels of U.S. monetary policy: The one that affects funding costs and the other that affects returns on safe assets. We restrict the sample to loans made to nonU.S. borrowers and focus on risk-taking by both U.S. and non-U.S. lenders. We posit that lenders conduct risk management at the highest level of consolidation. Therefore, to the extent permitted by the data, we assign loans made by immediate lenders to their parent organizations, that is, ultimate lenders. For example, we assign a loan made by a bank to that bank's holding company. The identification of the effects of U.S. interest rates on risk-taking is the strongest for non-U.S. lenders originating loans to non-U.S. borrowers, U.S. interest rates are likely to be exogenous to ex ante credit risk of such loans. To further strengthen the identification, we include various fixed effects in our regressions to control for unobserved factors. We construct regressions both at a loan-level and a lender portfolio-level. There is a trade-off between these regressions. On the one hand, loan-level regressions allow for the inclusion of more controls. On the other hand, portfoliolevel regressions are more pertinent because lenders ultimately think about ex ante credit risk of their loan portfolios, not just individual loans. We hypothesize that both lower costs of U.S. dollar

funding or lower returns on safe U.S. dollar asset - the two channels for risk-taking spillovers of U.S. interest rates - induce originations of ex ante riskier loans to non-U.S. borrowers. 


\subsubsection{Loan-level regressions}

We estimate the loan-level regression in a semi-log form because of the pronounced skewness of the distribution of the explained variable - loan EDFs:

$$
\begin{aligned}
& \log \left(\widehat{E D F}_{j, l, b, t}\right)= \alpha_{l}+\alpha_{b}+\underbrace{\beta_{F} R_{t}^{F}+\theta_{F} \operatorname{char}_{l} R_{t}^{F}+\beta_{T} R_{t}^{T}+\theta_{T} \operatorname{char}_{l} R_{t}^{T}+\mathbf{X}_{g, t} \gamma}_{\text {global pull factors }} \\
&+\underbrace{\mathbf{Z}_{c, t} \lambda}_{\text {local pushfactors }}+\varepsilon_{j, l, b, t}
\end{aligned}
$$

where $\widehat{E D F}_{j, l, b, t}$ is the projected EDF for loan $j$ made by lender $l$ to borrower $b$ (in country $c$ from country group $g$ ) at time $t . \alpha_{l}$ and $\alpha_{b}$ are lender and borrower fixed effects, respectively. $R_{t}^{F}$ is the federal funds rate and $R_{t}^{T}$ is the 10-year U.S. Treasury rate. $X_{t}$ is the vector of controls for risk appetite, economic uncertainty, U.S. inflation expectations, and U.S. dollar exchange rates against currencies of borrower country group $g$ (advanced economies or emerging markets); and $Z_{c, t}$ is the vector of borrower country controls. $\operatorname{char}_{l}$ is the dummy for a certain characteristic of lender $l$ : In the following regressions it either captures the nationality (U.S. vs non-U.S.) or type (bank vs shadow bank) of lender $l$. In some regressions, we replace borrower fixed effects with borrower country, industry, and debt rating fixed effects as another way to capture latent, time-invariant ex ante credit risk. $\varepsilon_{j, l, b, t}$ is a white noise error. We cluster errors by time, lender, and syndicate (because what we consider loan $j$ is lender $l$ 's stake of a syndicate of multiple lenders that lent to borrower $b)^{8}$ We do not consider a specification with time effects because we are interested in the general effects of the global factors $-\beta_{F}, \beta_{T}$, and $\gamma$.

We think of U.S. interest rates, risk appetite, economic uncertainty, U.S. inflation expectations, and U.S. dollar exchange rate indexes as global push factors of risk-taking. Because U.S. interest rates may reflect risk-on or risk-off market sentiment, we aim to isolate the effects of interest rates from those of market sentiment by controlling for various risk appetite and economic uncertainty measures. The risk sentiment factors include the two components of VIX - variance risk premium and conditional variance as in Bekaert, Hoerova, and Lo Duca (2013), Bekaert and Hoerova (2014), and Londono (2011) - to control for option-implied variance premium and uncertainty in equity markets. These components have been shown to be a good predictor of stock returns and financial instability. For the VIX components, we use updated series from Londono (2011) 9 The factors also comprise the Merrill Lynch low-grade corporate bond spread to measure risk appetite in the secondary high-yield corporate bond market and the spread between Italian and German sovereign yields to capture risk appetite around sovereign stress events in Europe 10 We define the spread as a difference of longer-term Italian and German sovereign yields because Italy is the fourth

\footnotetext{
${ }^{8}$ We rely on Petersen $(2009)$ for error clustering choices and on the estimator described in Correia $(2016)$.

9 Londono (2011) defines the variance premium as the difference between the risk neutral and the physical expectation of the market return variation between time $t$ and one month forward $t+1$.

${ }^{10}$ As Ratnovski, Claessens, and Cerutti (2017) find, select European factors contribute to global financial conditions and explain in part the behavior of cross-border bank flows.
} 
largest economy in the EU and adverse developments in this EU member state may have systemic implications for the bloc's economy and financial system and, therefore, those of the rest of the world ${ }^{11}$ This spread is highly positively correlated with the credit default swap (CDS) spread for Italian sovereign bonds. Moreover, the factors include the news-based economic policy uncertainty index of Baker, Bloom, and Davis (2016). This index comes from U.S. news sources that cover U.S. and international developments and, therefore, captures economic uncertainty about events in both the United States and abroad.

The global factors include U.S. dollar exchange rate indexes that are borrower country groupspecific to account for the possibility that U.S. dollar appreciations may reduce lenders' willingness to originate ex ante riskier loans ${ }^{12}$ Bruno and Shin (2015) show that U.S. dollar appreciations go hand-in-hand with contractions in cross-border lending and argue that banks contract lending when the dollar appreciates because of an increase in the risk on their balance sheets. (Note that their study uses aggregate, banking system-level foreign claims and does not inform about actual ex ante credit risk of these claims.) For instance, an appreciation of the U.S. dollar against borrower currencies may increase the debt servicing burden of borrowers' U.S. dollar loans in the absence of U.S. dollar revenues and foreign exchange hedges. The worsening of credit quality of loans on their balance sheets may induce lenders to originate less risky loans to maintain a desired level of credit risk in their portfolios. Because we can only observe the quality of loans being originated, we cannot explore this possibility in detail. In addition, because there is very limited information on nonU.S. public corporations' revenue currencies and foreign exchange hedges in general and because our sample is dominated by obscure, private borrowers in particular, we cannot offer meaningful controls for borrowers' exchange rate risk and debt servicing burdens. However, borrower-related fixed effects may capture some longer-term, time-invariant exchange rate risks - for example, those related to characteristics of borrower industries and nationalities 13

Finally, the global factors include survey-based U.S. inflation expectations: Because syndicated loans are floating rate loans, investors may gain an inflation hedge over fixed income securities of similar credit risk, such as high-yield corporate bonds. We use the survey-based expected inflation because the TIPS-based inflation compensation is not available before the early 2000s.

We think of borrower country controls as local pull factors. These factors include borrowercountry realized volatility in equity markets; growth rates of borrower-country real GDP; borrowercountry short-term interest rates as a proxy for local monetary policy; and borrower-country 10-year sovereign debt yields. Note that we include the 10-year sovereign debt yields only in regressions for the post-GFC period when the 10-year U.S. Treasury rate became the Federal Reserve's de facto policy rate. Because local implied volatility indexes, such as U.S. VIX, are generally not available, we use realized stock market volatility instead.

\footnotetext{
${ }^{11}$ The results are robust to exclusion of the spread, but then such a specification does not capture the effects of U.S. monetary policy on risk-taking in the post-crisis period as cleanly as that in the paper.

${ }^{12}$ The indexes are in currency units per U.S. dollar; an increase in the index indicates a U.S. dollar appreciation.

${ }^{13}$ In our robustness checks, we considered loans made to borrowers in industries that likely have a natural hedge against U.S. dollar movements such as commodity-related industries. This approach leads to a significant reduction in the sample size, but does not materially change the picture.
} 
We focus the most on the coefficients that capture the effects of U.S. interest rates on risktaking: The general effects $\beta_{F}$ and $\beta_{T}$ and the cross-sectional effects $\theta_{F}$ and $\theta_{T}$ which identify the importance of a given lender characteristic. We hypothesize that the general effects are negative: Lower costs of U.S. dollar funding or lower returns on U.S. dollar safe asset may induce originations of ex ante riskier loans to non-U.S. borrowers. We also hypothesize that the cross-sectional effects are negative too, at least for the post-GFC period because of the findings in Aramonte, Lee, and Stebunovs (2019) and in Barth, Caprio, and Levine (2001). Aramonte, Lee, and Stebunovs (2019) show that non-U.S. lenders - both banks and shadow banks - increased ex ante risk-taking in the U.S. syndicated term loan market in response to lower spot and forward longer-term U.S. Treasury rates, as well as in response to lower expected federal funds rates in the post-GFC period. Separately, Barth, Caprio, and Levine (2001) document the perception of more stringent regulation and higher-quality supervision of banks in the United States than in other countries which, we think, may result in more muted ex ante risk-taking by U.S. lenders than non-U.S. lenders in response to U.S. interest rates. We do not exclude other reasons that may support the hypothesis of the negative cross-sectional effects.

We estimate equation 2 separately for the pre- and post-GFC periods because of a potential structural break around the crisis. For the pre-crisis period, we include both short- and longer-term U.S. interest rates to test whether the two risk-taking channels of U.S. monetary policy operated simultaneously. We considered an alternative specification with the federal funds rate and the slope of the U.S. yield curve (defined as the spread of the 10-year U.S. Treasury rate over the federal funds rate), but we decided against it. The inclusion of the slope is equivalent to imposing a constraint on the coefficients of its components: The coefficients are restricted to be of the same absolute magnitude but of the opposite signs. We prefer the data to speak about any coefficient restrictions. For the post-crisis period, we include only the U.S. Treasury rate because the federal funds rate was at the zero lower bound beginning in 2008:Q4. Again, we considered an alternative specification with the slope but rejected it. Because the federal funds rate was at the zero lower bound, changes in the slope were driven by the level of the 10-year Treasury rate. We note though that we cannot exclude that the low cost of short-term U.S. dollar funding was not a contributing factor in the post crisis period because short-term U.S. interest rates were low.

Because equation 2 is a semi-log model, we construct marginal effects of changes in U.S. interest rates and other factors around a reference point - the sample average of the dependent variable which we denote by $\widehat{\widehat{E D F}}$. For example, the formula for the marginal effect (in basis points) of a one standard deviation change in the federal funds rate is: $\widehat{\triangle E D F}=100 \times \widehat{\widehat{E D F}} \times \beta_{F} \times$ stand.dev.F. 


\subsubsection{Portfolio-level regressions}

We construct the portfolio-level regression by analogy with the loan-level regression:

$$
\begin{aligned}
& \log \left(\widehat{\widehat{E D F}}_{l, g, t}\right)= \\
& \alpha_{l}+\alpha_{g}+\underbrace{\beta_{F} R_{t}^{F}+\theta_{F} R_{t}^{F} \operatorname{char}_{l, t}+\beta_{T} R_{t}^{T}+\theta_{T} R_{t}^{T} \operatorname{char}_{l, t}+\text { pchar }_{l, t}+\mathbf{X}_{g, t} \gamma}_{\text {global pull factors }} \\
& +\underbrace{\overline{\mathbf{Z}}_{\mathbf{l , g}, \mathbf{t}} \lambda}_{\text {local push factors }}+\varepsilon_{l, g, t}
\end{aligned}
$$

where $\widehat{\widehat{E D F}}_{l, g, t}$ is the simple average of EDFs projected for loans originated by lender $l$ to borrowers from country group $g$ (advanced economies or emerging markets) at time $t . \alpha_{l}$ and $\alpha_{g}$ are lender and country group fixed effects, respectively. $\mathbf{X}_{g, t}$ is the vector of controls for risk appetite, economic uncertainty, U.S. inflation expectations, and U.S. dollar exchange rates against currencies of borrower country group $g . \overline{\mathbf{Z}}_{\mathbf{l}, \mathbf{g}, \mathbf{t}}$ is the simple average of local factors (realized volatility, growth rates of real GDP, and interest rates) for borrower countries in country group $g$ where lender $l$ lends. $\operatorname{char}_{l, t}$ is a dummy for a certain characteristic of lender $l$ : In the following regressions, it either captures the nationality (U.S. vs non-U.S.), type (bank vs bank shadow), or capitalization level (low vs high) of lender $l . \varepsilon_{l, g, t}$ is a white noise error. We cluster errors by time and lender. We do not consider a specification with time fixed effects because we are interested in the general effects of global factors $-\beta_{F}, \beta_{T}$, and $\gamma$.

As with the loan-level regression, we focus primarily on the coefficients that capture the effects of U.S. interest rates on risk-taking: The general effects $\beta_{F}$ and $\beta_{T}$ and the cross-sectional effects $\theta_{F}$ and $\theta_{T}$, which identify the importance of a given lender characteristic. Yet again, we hypothesize that the general effects are negative (lower U.S. interest rates induce originations of ex ante riskier loans) and that the cross-sectional effects for the nationality and type of lender are negative too. (Note that for lender $l$, the nationality and type do not change over time, so the subscript $t$ can be dropped from $\operatorname{char}_{l, t}$.) We estimate equation 2 separately for the pre- and post-GFC periods because of a potential structural break around the crisis. For the pre-crisis period, we include both short- and longer-term U.S. interest rates to test whether the two risk-taking spillover channels operated simultaneously. For the post-crisis period, we include only the U.S. Treasury rate because the federal funds rate was at the zero lower bound beginning in 2008:Q4.

In the portfolio-level regressions, we introduce a new lender characteristic - the level of lender capitalization. We take a cue from Dell'Ariccia, Laeven, and Suarez (2017), who find that ex ante risk-taking by U.S. banks (measured by the risk rating of new loans) in originations of small, domestic, non-syndicated business loans is negatively associated with increases in short-term U.S. interest rates. They also find that this relationship is less pronounced for banks with relatively low capital. ${ }^{14}$ However, we differ from Dell'Ariccia, Laeven, and Suarez (2017) in many respects. We study risk-taking in response to longer-term U.S. interest rates by U.S. and non-U.S. banks and

\footnotetext{
${ }^{14}$ While the sample in Dell'Ariccia, Laeven, and Suarez (2017) covers 1997 to 2011, we attribute their findings mostly to the pre-crisis period because of the zero lower bound.
} 
shadow banks in a global, very large market for large corporate loans that are made to non-U.S., mostly leveraged borrowers. Put differently, we study not only a different loan market, but also emphasize a different risk-taking channel of U.S. monetary policy. Yet we hypothesize that the cross-sectional finding of Dell'Ariccia, Laeven, and Suarez (2017) caries through. We think that, given the overall environment, including tightened supervisory scrutiny, banks with relative low capital were more likely in the post-crisis period to preserve their capital rather than gamble for resurrection.

We explore two definitions of the lender capitalization characteristic. First, we define it as a dummy that is equal to 1 if lender $l$ (either a bank or a shadow bank) is headquartered in a country in which aggregate Tier 1 risk-based capital ratio is in the bottom 25th percentile of the distribution of such country-level ratios at time $t$. We construct these distributions from the IMF's FSI statistics. Second, we define this characteristic as a dummy that is equal to 1 if lender $l$ (a bank) has an equity-over-assets ratio (a proxy for leverage) that is in the bottom 25th percentile of the distribution of such bank-level ratios at time $t$. We construct these distributions from the Moody's Analytics BankFocus data. We merge the DealScan and BankFocus data by lender legal name using the algorithm of Cohen, Friedrichs, Gupta, Hayes, Lee, Marsh, Mislang, Shaton, and Sicilian (2018). Note that this new characteristic - no matter the definition - varies over time for lender l. For this bank-level capitalization analysis, we retain only loans where banks act as arrangers because they are more likely to retain significant stakes (and, therefore, ex ante credit risk) in these loans post origination. Because the first definition is broader, the regressions that rely on this definition include a significantly higher number of lenders. We estimate equation 3 only for the post-GFC periods because of data limitations (for example, because of a change in an international accounting standard in the mid-2000s).

Because equation 3 is a semi-log model, we construct marginal effects of changes in factors around a reference point by analogy with those for equation 2 .

\section{Estimation results}

In this section, we present the estimation results for the EDF regressions that map loan and borrower characteristics into loan default probabilities and the loan- and portfolio-level regressions that capture the global risk-taking channel of U.S. monetary policy. In the latter, we differentiate ex ante risk-taking in response to U.S. interest rates by lender nationality and by lender type. In addition, in the portfolio-level analysis, we differentiate risk-taking by lender capitalization.

Table 3 lists countries of borrowers that appear in the loan- and portfolio-level samples: It is a mix of 19 advanced economies and 15 emerging markets, with a wide range of borrower credit quality in each country group. Reasons that determine the country coverage include the availability of actual and projected EDFs as well as local factors. 


\subsection{Construction of EDFs}

Table 1 shows summary statistics for the matched sample of loans and borrower EDFs in the pre- and post-crisis periods. We take logs of EDFs because of their skewed distribution. The differences between loans originated in the two periods are striking: The pre-crisis loans were ex ante safer, cheaper, and longer - all by significant margins.

Figure 3 - a scatter-plot of the maturity-matched EDFs and loan spreads - illustrates that loan spreads are important in understanding the probability of default of a given loan. The loan spreads and the other variables explain about 40 to 50 percent of variation in $\log (E D F)$ s in the preand post-GFC periods, respectively. As the comparison of adjusted R-squareds and within Rsquareds suggests, fixed effects captured over half of the explained variation. We could improve marginally the within goodness of fit by including additional loan characteristics, but that would limit the number of loans for which we could project EDFs out of the sample. Figure 4- a scatter plot of maturity-matched EDFs and projected $\widehat{E D F}$ - showcases that equation 1 provides a high degree of goodness of fit. This scatter plot also suggests that this regression tends to under-project somewhat the riskiness of the riskiest loans. This downward bias works against us because the mass of originations of high-risk, leveraged loans was quite significant, particularly in the postcrisis period.

We report the estimation results for the pre-crisis period in column (1) and for the post-crisis period in column (2) of table 2. As expected, in both periods, EDFs are positively correlated with loan spreads, negatively correlated with loan amounts, and positively correlated with loan maturity.

Using equation 1 , we project $\widehat{E D F} \mathrm{~s}$, which increases the number of loans for which probabilities of default are available from about 790 in the pre-crisis period and 430 in the post-crisis periods to about 5700 and 2080 loans in the respective periods, nearly matching the number of all loans in our data. Because loans tend to have multiple lenders at origination, the number of loan-lender matched observations jumps even more, reaching 28,900 and 10,400 for the pre- and post-crisis periods, respectively.

Figure 5 shows the densities of the actual and projected EDFs. (For presentation purposes, we do not show the entire long right tails of the distributions in the figure.) Obviously, the two distributions do not necessarily have to be identical because the actual EDFs are based only on a subset of borrowers for which these metrics can be constructed. Nevertheless, the distributions paint similar pictures. They both point at a shift toward originations of riskier loans in the post-crisis period.

Figure 6 shows the negative relationship between $\widehat{E D F}$ s and the federal funds rate in the precrisis period (the left panel) and the 10-year U.S. Treasury rate in the post-crisis period (the right panel). In the post-crisis period, while short-term interest rates stayed near zero, the 10-year U.S. Treasury rates declined initially but rebounded notably in 2012-13, with the taper tantrum.

In the loan-level analysis, we use $\widehat{E D F}$ s as the main dependent variable. In the portfoliolevel analysis, we average those metrics across multiple loans to estimate the risk of a portfolio of loans for a given lender. From a risk management perspective, lenders care more about credit risk of portfolios that they originate than about credit risk of individual loans in those portfolios. 
Therefore, for completeness, we estimate models at both the loan and portfolio levels. The question then is what global and local factors explain the shift in ex ante credit risk.

\subsection{Loan-level regressions}

Table 4 reports summary statistics for the pre- and post-GFC samples used in the loan-level regressions. Overall, the pre-GFC period is characterized by originations of loans of lower ex ante credit risk (lower $\widehat{E D F} \mathrm{~s}$ ), higher short- and longer-term interest rates, and lower readings of risk appetite and economic uncertainty measures than those in the post-GFC period.

Loans originated by U.S. and non-U.S. lenders We first estimate equation 2 that differentiates ex ante risk-taking in response to U.S. interest rates by lender nationality. That is, we set $\operatorname{char}_{l}$ equal to 1 if lender $l$ is a non-U.S. lender. We show the estimation results in table 5 . Columns (1) and (2) show the results for the specification with lender and borrower fixed effects for the pre- and post-crisis periods, respectively. Columns (3) and (4) show the results for the specification with lender fixed effects and borrower country, industry, and debt rating fixed effects for the pre- and post-crisis periods, respectively.

We focus on the coefficients that capture the effects of U.S. interest rates on risk-taking. As we hypothesized, the estimates of the general effects, $\hat{\beta}_{F} \mathrm{~s}$ and $\hat{\beta}_{T} \mathrm{~s}$, are negative and statistically significant. The magnitudes of the estimated coefficients are very similar across the specifications, at 0.07 , on average, for the $\hat{\beta}_{F}$ and at 0.26 , on average, for the $\hat{\beta}_{T}$. The averages of the estimates coefficients imply that, around the respective sample averages of $\widehat{E D F} \mathrm{~s}$, a decrease in the federal funds rate of one standard deviation results in an increase of 14 basis point in $\widehat{E D F}_{\mathrm{s}}$, which reach 1.23 percent in the pre-crisis period 15 Similarly, a decrease in the 10-year U.S. Treasury rate of one standard deviation results in an increase of 24 basis points in $\widehat{E D F}$ s, which reach 1.43 percent in the post-crisis period. Because the $\widehat{E D F}$ distributions are skewed (there is a large mass of ex ante very risky loans in the sample), we repeat the same exercise around the 75 th percentiles of $\widehat{E D F}$ s rather than the averages of $\widehat{E D F}$ s. Now, a decrease in the federal funds rate of one standard deviation results in an increase of 28 basis point in $\widehat{E D F} \mathrm{~s}$, which reach 2.50 percent in the pre-crisis period. In the same way, a decrease in the 10-year U.S. Treasury rate of one standard deviation results in an increase of 45 basis points in $\widehat{E D F} \mathrm{~s}$, which reach 2.70 percent in the post-crisis period.

One can put the sample averages of $\widehat{E D F}$ s and the general effects into a credit ratings context. Per Aramonte, Lee, and Stebunovs (2019), probabilities of default for speculative grade borrowers typically range between 35 and 800 basis points, with a median of 180 basis points ${ }^{16}$ Therefore, lower U.S. interest rates appear to encourage lenders who typically lend to speculative grade borrowers to originate even ex ante riskier loans to such borrowers. This effect is stronger for lenders that specialize in particularly risky loans (because their reference $\widehat{E D F} \mathrm{~s}$ are higher, the general

\footnotetext{
${ }^{15}$ These sample averages do not differentiate the riskiness of loans originated by U.S. and non-U.S. lenders. We show only statistically significant general marginal effects.

${ }^{16}$ Strictly speaking, their statistics apply only to our post-crisis sample because they are based on a limited 2010-13 sample.
} 
effects are higher for them). Overall, we conclude that the general effects of one standard deviation changes in U.S. interest rates were material, especially in the post-crisis period.

We now turn to the cross-sectional effects $\theta_{F}$ and $\theta_{T}$, which identify the importance of lender nationality. While we hypothesized that the cross-sectional effects are negative (meaning that non-U.S. lenders' risk-taking increases more when U.S. interest rates decrease), the estimation results suggest that there is no practical difference in risk-taking of U.S. and non-U.S. lenders in both periods. The estimated coefficients $\hat{\theta}_{F}$ and $\hat{\theta}_{T}$ are (mostly) small, positive, and statistically insignificant.

As for the other global push factors, we find that, in the pre-crisis period, lenders originated less risky loans in response to U.S. dollar appreciation. The U.S. dollar exchange rate factor operated along with the U.S. interest rate factor likely because at least some U.S. exchange rate movements were not associated with U.S. monetary policy. The average of the estimated coefficients on the U.S. dollar exchange rate implies that, around the sample average off $\widehat{E D F}$ s, a U.S. dollar appreciation of one standard deviation results in a decrease of 25 basis points in $\widehat{E D F} \mathrm{~s}$, which reach 0.85 percent in the pre-crisis period. We conjecture that the U.S. dollar exchange rate factor has likely remained relevant in the post-crisis period. But we cannot estimate its more recent effects precisely because our post-crisis sample is short and shows four times lower variation in the U.S. dollar exchange rate indexes.

We also find that, across the periods, the responses to changes in risk appetite and economic uncertainty varied. The pattern that emerges is the following: Lenders originated ex ante riskier loans in response to higher low-grade bond spreads and higher borrower country realized volatility in the pre-crisis period and higher conditional variance and higher European sovereign spreads in the post-crisis period. Overall, the global risk appetite and economic uncertainty factors appear to be more important factors. All other factors are not statistically significant across the specifications for the same periods.

We summarize the statistically significant general marginal effects in table 6 for a one standard deviation decrease in a given factor. As a reminder, they are constructed using the averages of the estimated coefficients $\beta_{F}$ and $\beta_{T}$ across the specifications around the sample averages of projected EDFs (because equation 2 is a semi-log model). The magnitudes suggest that the effects of U.S. interest rates on risk-taking are comparable to those of the other statistically significant factors. Therefore, we conclude that global risk-taking spillovers of U.S. monetary policy are important but not dominant factors for risk-taking in the market. Note that, in this instance, we do not consider cross-sectional marginal effects because they are mostly statistically insignificant.

Loans originated by banks and shadow banks Next, we estimate equation 2, which differentiates ex ante risk-taking in response to U.S. interest rates by lender type. That is, we set $\operatorname{char}_{l}$ equal to 1 if lender $l$ is a nonbank. We show the estimation results in table 7 . The coefficients on the variables that carry over from table 5 -including the general effects $\hat{\beta}_{F} \mathrm{~s}$ and $\hat{\beta}_{T} \mathrm{~s}$ - change very little. The cross-sectional effects $\theta_{F}$ and $\theta_{T}$, which identify the importance of lender type, suggest the following. Shadow banks did not originate ex ante riskier loans than banks did in response to lower federal funds rates in the pre-crisis period. However, shadow banks did originate 
ex ante riskier loans than banks did in response to lower U.S. Treasury rate in the post-crisis period. We do not explore in detail reasons for the change in signs and statistical significance of these responses. It may be that, before the crisis, nonbanks did not fund their short-term liabilities at the federal funds rate to the same extent as banks did. Or it may be that, before the crisis, especially in the 1990s, not enough nonbank lenders participated in loan syndication and, thus, appeared in the sample for meaningful results. Moving to marginal cross-sectional effects around the sample average of $\widehat{E D F} \mathrm{~s}$, the average of the estimated coefficients implies that a decrease in the U.S. Treasury rate of one standard deviation results in an increase of 2 basis points in $\widehat{E D F}$ s. In addition, the general effect of lower U.S. interest rates is a 24 basis point increase in $\widehat{E D F}$ s. We conclude that while nonbank lenders did originate ex ante riskier loans than banks did in the postcrisis period, their additional risk-taking was negligible. The findings suggest that the presence of frictions is not a necessary condition for financial intermediaries to take on higher ex ante credit risk as interest rates decline. They remind of the portfolio allocation theory (as in Fishburn and Porter (1976)) that is applicable to a variety of types of financial intermediaries and predicts that the optimal proportion invested in risky assets will increase with a decrease in returns on safe assets.

\subsection{Portfolio-level regressions}

Table 8 reports summary statistics for the dependent variable in equation $3-\overline{\overline{E D F}}_{l, g, t}$, which is the simple average of $\log (\widehat{E D F}) \mathrm{s}$ of loans in portfolio $g$ of lender $l$. We highlight two observations. First, the sample averages of $\widehat{\widehat{E D F}}_{l, g, t} \mathrm{~s}$ for advanced economies are notably lower than those for emerging markets, no matter the period. Second, the pre-GFC period is characterized by originations of loan portfolios of notably lower ex ante credit risk.

Portfolios originated by U.S. and non-U.S. lenders We first estimate equation 3, which differentiates ex ante risk-taking in response to U.S. interest rates by lender nationality. That is, we set $\operatorname{char}_{l}$ equal to 1 if lender $l$ is a non-U.S. headquartered lender. We show the estimation results in table 9. Columns (1) and (2) show the results for the pre- and post-crisis periods, respectively.

We focus on the coefficients that capture the effects of U.S. interest rates on risk-taking. As we hypothesized, the estimates of the general effects, $\hat{\beta}_{F}$ and $\hat{\beta}_{T}$, are negative and statistically significant. The magnitudes of the estimated coefficients, at -0.07 and -0.19 , respectively, are very similar to those for the loan-level regressions in columns (1) and (2) in table 5 . These averaged estimates imply that, around the sample averages of $\overline{\overline{E D F}_{\mathrm{D}}}$ for advanced economies, a decrease in the federal funds rate of one standard deviation results in an increase of 9 basis points in $\widehat{\widehat{E D F}}_{\mathrm{s}}$, which would reach 0.85 percent in the pre-crisis period. Similarly, for advanced economies' portfolios, a decrease in the 10-year U.S. Treasury rate of one standard deviation results in an increase of 16 basis points in $\overline{\widehat{E D F}} \mathrm{~s}$, which would reach 1.25 percent in the post-crisis period. The estimates also imply that, around the sample averages of $\overline{\overline{E D F}}_{\mathrm{s}}$ for emerging markets, a decrease in the federal funds rate of one standard deviation results in an increase of 16 basis point in $\overline{\widehat{E D F}_{\mathrm{S}}}$, which would reach 1.39 percent in the pre-crisis period. By the same token, for emerging markets' portfolios, a decrease in the 10-year U.S. Treasury rate of one standard deviation results in an 
increase of 27 basis points in $\overline{\widehat{E D F}}$ s, which would reach 1.62 percent in the post-crisis period. These marginal effects suggest that lenders originated notably ex ante riskier loans to borrowers from emerging markets than to those from advanced economies. That is, the spillovers of U.S. monetary policy on risk-taking were stronger for emerging markets than advanced economies. Overall, we still conclude that the effects of one standard deviation changes in U.S. interest rates were material but far from dominant for the quality of loans being originated in either borrower country group.

We now turn to the cross-sectional effects $\theta_{F}$ and $\theta_{T}$, which identify the importance of lender nationality. While we hypothesized that the cross-sectional effects are negative, the estimation results for the pre-crisis period suggest that non-U.S. lenders' risk-taking increases less than that of U.S. lenders when federal funds rates decrease. (It is possible that non-U.S. lenders rely less than their U.S. peers on short-term liabilities that are funded at the federal funds rate, so the cost-ofU.S dollar funds channel does not apply.) However, the estimation results for the post-crisis period do support the hypothesis of the negative cross-sectional effects. The estimated coefficient $\hat{\theta}_{T}$ is negative and statistically significant. It implies that, in addition to the respective general effects, a decrease in the U.S. Treasury rate of one standard deviation results in an increase of 9 basis points in $\overline{\widehat{E D F}_{\mathrm{E}}}$ s of advanced economies' portfolios and an increase of 11 basis points in $\overline{\widehat{E D F}}$ s of emerging markets' portfolios. We conclude that while non-U.S. lenders took on more ex ante credit risk than their U.S. peers did in the post-crisis period, their additional risk-taking was material.

As for the other global push factors, we find that the results are similar to those in table 5 . In the pre-crisis period, lenders originated less risky loans in response to U.S. dollar appreciation. Across the periods, the responses to changes in risk appetite and economic uncertainty varied. The pattern that carries over is the following: Lenders originated ex ante riskier loans in response to higher low-grade bond spreads and higher borrower country realized volatility in the pre-crisis period and higher conditional variance and higher European sovereign spreads (nearly statistical significant) in the post-crisis period. We note a new finding: Lenders originated ex ante riskier loan portfolios in response to lower economic uncertainty (captured by Baker, Bloom, and Davis (2016)'s index) in the post-crisis period. Again, the global factors appear to be more important than the local ones.

Portfolios originated by banks and shadow banks Next, we estimate equation 3, which differentiates ex ante risk-taking in response to U.S. interest rates by lender type. That is, we set $\operatorname{char}_{l}$ equal to 1 if lender $l$ is a nonbank lender. We show the estimation results in table 10 . The results for all lenders are in columns (1) and (2) and the results for non-U.S. lenders are in columns (3) and (4). We mostly focus on the latter because this specification further strengthens identification of risk-taking spillovers of U.S. monetary policy as the Federal Reserve is less likely to respond to financial conditions of non-U.S. lenders and borrowers. The coefficients on the variables that carry over from table 9 change little. The cross-sectional effects $\theta_{F}$ and $\theta_{T}$, which identify the importance of lender type, suggest the following. Non-U.S. shadow banks (as well as U.S. shadow banks) did not originate ex ante riskier loans than their respective bank peers did in response to lower federal funds rates in the pre-crisis period. However, non-U.S. nonbank lenders originated ex ante riskier loans than the other lenders did in response to lower U.S. Treasury rate 
in the post crisis period. Moving to cross-sectional marginal effects around the sample average of $\widehat{\widehat{E D F}}_{\mathrm{S}}$, the average of the estimated coefficients implies that a decrease in the U.S. Treasury rate of one standard deviation results in an increase of 9 basis points and 11 basis points in $\widehat{\overline{E D F}}_{\mathrm{S}}$ in advanced economies' and emerging markets' portfolios, respectively. In addition, the general effects are a 24 basis point increase in advanced economies, $\widehat{\widehat{E D F}}$ s and a 29 basis point increase in emerging markets' $\overline{\widehat{E D F}}$ s. We conclude that non-U.S. nonbank lenders originated ex ante riskier loan portfolios than the other lenders did in the post-crisis period, and their additional risk-taking was material.

Portfolios originated by low and high capitalization lenders Finally, we estimate equation 3 , which differentiates ex ante risk-taking in response to U.S. interest rates by lender capitalization in the post-GFC period. We explore two definitions of the lender capitalization dummy. First, we set $\operatorname{char}_{l, t}$ equal to 1 if lender $l$ (either a bank or a nonbank) is headquartered in a country in which the aggregate Tier 1 risk-based capital ratio is in the bottom 25th percentile of the distribution of such country-level ratios at time $t$. Second, we set char $_{l, t}$ equal to 1 if lender $l$ (a bank) has an equity-over-assets ratio (a proxy for leverage) in the bottom 25th percentile of the distribution of such bank-level ratios at time $t$.

We show the estimation results in table 11; The results for the country-level capitalization dummy are in columns (1) and (2) for all lenders and all non-U.S. lenders, respectively. The results for the bank-level capitalization dummy are in columns (3) and (4) for all banks and all non-U.S. banks, respectively. Because the first definition is broader, the regressions in columns (1) and (2) have a significantly higher number of lenders (over 200) than in columns (3) and (4) (over 100) ${ }^{17}$ The sample in column (1) has lenders from 43 advanced economies and emerging markets, with U.S. lenders accounting for nearly one fifth of observations and emerging economies' lenders for over one fourth. In turn, the sample in column (3) has banks from 36 advanced economies and emerging markets, with U.S. banks accounting for over one tenth of observations and emerging economies' lenders for about one third.

We focus on the coefficients that capture the effects of U.S. interest rates on risk-taking. The estimates of the general effects, $\hat{\beta}_{F}$ and $\hat{\beta}_{T}$, are negative and statistically significant. The magnitudes of the estimated coefficients, ranging between -0.38 and -0.43 , are notably higher than those for the regressions in columns (2) and (4) in table 9. These estimates imply that, around the sample averages of $\widehat{\widehat{E D F}}_{\mathrm{S}}$ of the respective samples, a decrease in the 10-year U.S. Treasury rate of one standard deviation results in an increase of 30 to 46 basis points in $\widehat{E D F}_{\mathrm{E}}$, which would reach 1.31 to 1.85 percent.

We now turn to the cross-sectional effects $\theta_{T}$ and $\eta$, which identify the importance of lender capitalization. We hypothesized that the cross-sectional effect $\theta_{T}$ is positive (lenders with relatively low capital originate less ex ante risky loan portfolios when longer-term U.S. rates decline than the other lenders do) and $\eta$ is negative (lenders with relatively low capital engage originate less ex ante risky loan portfolios in general). The estimation results support these hypotheses. The

\footnotetext{
${ }^{17}$ We implicitly assume that aggregate capital ratios for banks are indicative of the level of capitalization of nonbank lenders.
} 
estimated coefficients $\hat{\theta}_{T}$ s are positive and statistically significant in all four specifications: They range between 0.10 and 0.21 . These estimates imply that, around the sample averages of $\widehat{\widehat{E D F}}_{l, g, t} \mathrm{~s}$ in the respective samples, these cross-section effects offset the general effects from a decrease in the 10-year U.S. Treasury rate of one standard deviation by 8 to 21 basis points. As for the crosssectional effect $\eta$, it is negative and statistically significant in three out of four specifications. Across the three specifications, the estimates suggest that lenders with weaker capitalization originated loan portfolios with $\overline{\widehat{E D F}}$ s 40 to 80 basis points lower than lenders with stronger capitalization did. We conclude that lenders with weaker capitalization originated significantly less ex ante risky loan portfolios than lenders with stronger capitalization did in general and in response to lower longer-term U.S interest rates.

Overall, the cross-section results are consistent with weaker banks trying to preserve their capital rather than gamble for resurrection. While Dell'Ariccia, Laeven, and Suarez (2017) found similar evidence, our channel differs from theirs in many ways. They examine a domestic risk-taking channel of conventional U.S. monetary policy that operates through U.S. banks. In contrast, we study a global risk-taking channel of unconventional U.S. monetary policy that operates through U.S. and non-U.S. lenders. Put differently, we study ex ante risk-taking by U.S. and non-U.S. lenders in response to the returns on safer U.S. dollar assets rather than the cost of U.S. dollar funding. We emphasize risk rebalancing as lenders substitute away from safer to riskier assets when longer-term U.S. interest rates decline. This channel does not necessarily rely on the presence of asymmetric information frictions and government-insured short-term funding, such as deposits. Because we only study the post-crisis period, we cannot say for certain that lenders with weaker capitalization always behave this way. It may be that, in the context of the post-crisis period, the attenuated risk-taking behavior of less capitalized banks reflects a clampdown by regulators and supervisors of these banks' risk-taking activities. Indeed, a comparison of the general and crosssectional effects in columns (3) and (4) suggests that the quality of regulation and supervision may matter. U.S. banks with weaker capitalization, which are in column (3) but not (4), appear to attenuate the general and cross-sectional effects.

\subsection{Checks and caveats}

We did several robustness checks. For example, we estimated loan- and portfolio-level regressions that excluded lenders from the United States and a few major advanced economies. We argue that these regressions offer a clean identification of risk-taking spillovers of U.S. monetary policy as the Federal Reserve's policies did not respond to financial conditions of non-U.S. lenders and borrowers that remained in the sample. The cost of this approach is that the sample size shrinks and that the mass of larger, globally active lenders shrinks too. These regressions yielded similar results (not shown).

We acknowledge that our work has some caveats. First, we do not observe lenders' entire portfolios, which may include a variety of other financial instruments, not just syndicated loans. For example, lenders may hedge exposures to the syndicated term loan market in other financial markets. In this case, additional risk-taking in the syndicated loan market as a result of low U.S. 
interest rates may not necessarily represent a general increase in the riskiness of a given lender's assets. Second, a number of central banks in advanced economies, not just the Federal Reserve, pursued expansionary monetary policies in the aftermath of the GFC. Therefore, both U.S. and other major advanced economy interest rates may have affected lenders' incentives to take higher ex ante credit risk in the global syndicated loan market. However, because we control for monetary policy rates and longer-term rates in advanced economies (and emerging markets), these concerns are mitigated if not eliminated.

We also admit that our measure of ex ante credit risk-probability of borrower default - is incomplete. It is one of the two components of expected loss, with the other component being loss given default. Given data limitations, any estimates of losses given default will likely be highly inaccurate. But it is likely that losses given default had increased significantly over the sample period because of the proliferation of "covenant lite" loans, which had been in high demand from shadow banks. In general, covenant lite loans are riskier than other syndicated loans because they have few if any covenants to protect the lenders, such as restrictions on the borrowers regarding payment terms, income requirements, and asset disposals. Therefore, the omission of losses given default from analysis does not appear to be essential, because the proliferation of "covenant lite" loans works in our favor.

\section{Conclusions}

To the extent that actions of the Federal Reserve affect U.S. interest rates, we provide evidence of global risk-taking spillovers of U.S. monetary policy in the market for U.S. dollar syndicated term loans. We find that, before the GFC, both U.S. and non-U.S. lenders originated ex ante riskier loans to non-U.S. borrowers in response to a decline in short-term U.S. interest rates and, after the crisis, in response to a decline in longer-term U.S. interest rates. After the crisis, this behavior was more prominent for shadow banks. Turning to the portfolio-level analysis, we find that nonU.S. lenders originated ex ante riskier loan portfolios than U.S. lenders in response to a decline in longer-term U.S. interest rates. Next, we find that non-U.S. shadow banks originated ex ante riskier loan portfolios than non-U.S. banks in response to a decline in longer-term U.S. interest rates. Finally, we find that originations of ex ante riskier loan portfolios was less prominent for banks with relatively low capital. Separately, the findings suggest that informational frictions and limited liability are not necessary ingredients for risk-taking by financial intermediaries in the market.

As for the other global push factors, we find that, in the pre-crisis period, lenders originated less risky loans in response to U.S. dollar appreciation. We also find that, across the periods, the responses to changes in risk appetite and economic uncertainty varied. The patterns that emerged are the following. Lenders originated ex ante riskier loans in response to higher low-grade bond spreads and higher borrower country realized volatility in the pre-crisis period and higher conditional variance and higher European sovereign spreads in the post-crisis period. Lenders originated ex ante riskier loan portfolios in response to higher low-grade bond spreads in the precrisis period and higher conditional variance and lower economic uncertainty in the post-crisis period. To summarize across all the specifications, originations of ex ante riskier loans went hand- 
in-hand with higher low-grade bond spreads in the pre-crisis period and higher conditional variance in the post-crisis period.

Turning to local pull factors, we find that lenders originated ex ante riskier loans in response to higher realized volatility in the pre-crisis period, lower GDP growth in the post-crisis period, and higher interest rates in general.

Our analysis of the marginal effects of global push (and local pull) factors suggests that global risk-taking spillovers of U.S. monetary policy are important but not dominant factors for risktaking in the global market for U.S. dollar syndicated term loans. Indeed, the magnitudes of the marginal effects of U.S. interest rates on risk-taking are comparable to those of the other statistically significant factors. Typically, a change of one standard deviation in a given factor resulted in a material change of up to a couple of dozen basis points in probabilities of default of loans being originated. We also document that, in terms of marginal effects, the effects of U.S. monetary policy were stronger for lenders that specialize in particularly risky loans. Similarly, the spillovers of U.S. monetary policy on risk-taking were stronger for lending to borrowers in emerging markets than for lending to borrowers in advanced economies.

The existence of global risk-taking spillovers of the Federal Reserve's monetary policy highlights two potential financial stability challenges. First, other central banks may find it harder to have an effect on risk-taking in their countries in the presence of large, globally active lenders whose risktaking decisions are, in part, driven by U.S. monetary policy. Second, the presence of such lenders implies that build-ups in ex ante credit risk are global in nature. These lenders (typically banks) originate riskier loans in the global primary market, partly sell them off to other lenders (typically shadow banks) in the global secondary market, and hedge potential loan defaults (exposing their hedge counterparties to such defaults) in the global CDS market, which is concentrated ${ }^{18}$ Hence, additional risk-taking by globally active lenders could strain the global financial system. To this end, central banks may have to rely on coordination of multiple policy tools, such as monetary and macro-prudential policies, to ensure both economic and financial stability (for policy discussions related to the global financial cycle, see Rey (2015)). We note though that global risk-taking spillovers of U.S. monetary policy in the aftermath of the GFC may have aided the global economic recovery, but characterizing such effects lies outside the scope of the paper.

\section{References}

Altunbas, Y., L. Gambacorta, and D. Marques-Ibanez (2014): "Does Monetary Policy Affect Bank Risk?," International Journal of Central Banking, 10(1), 95-136.

Aramonte, S., S. J. Lee, and V. Stebunovs (2019): "Risk Taking and Low Longerterm Interest Rates: Evidence from the U.S. Syndicated Loan Market," Journal of Banking and Finance, forthcoming.

\footnotetext{
${ }^{18}$ See Stulz $(2010)$ for the features of the global CDS market.
} 
Argimon, I., C. Bonner, R. Correa, P. Duijm, J. Frost, J. De HaAn, L. De HaAn, and V. Stebunovs (2019): "Financial Institutions Business Models and the Global Transmission of Monetary Policy," Journal of International Money and Finance, 90, 99117.

Baker, S., N. Bloom, and S. Davis (2016): "Measuring Economic Policy Uncertainty," Quarterly Journal of Economics, 131(4), 1593-1636.

Barth, J. R., G. Caprio, and R. Levine (2001): "The Regulation and Supervision of Banks around the World : A New Database," Policy Research Working Paper 2588, World Bank.

Bekaert, G., And M. Hoerova (2014): "The VIX, the Variance Premium, and Stock Market Volatility," Journal of Econometrics, 183(2), 181-192.

Bekaert, G., M. Hoerova, and M. Lo Duca (2013): "Risk, Uncertainty, and Monetary Policy," Journal of Monetary Economics, 60(7), 771-788.

Bruno, V., And H. S. Shin (2015): "Capital Flows and the Risk-Taking Channel of Monetary Policy," Journal of Monetary Economics, 71, 119-132.

Carey, M., and G. Nini (2007): "Is the Corporate Loan Market Globally Integrated? A Pricing Puzzle," Journal of Finance, 62(6), 2969-3007.

Cetorelli, N., and L. S. Goldberg (2012): "Banking Globalization and Monetary Transmission," Journal of Finance, 67(5), 1811-1843.

Chodorow-Reich, G. (2014): "Effects of Unconventional Monetary Policy on Financial Institutions," Brookings Papers on Economic Activity, 48(1 (Spring), 155-227.

Cohen, G., M. Friedrichs, K. Gupta, W. Hayes, S. J. Lee, B. Marsh, N. MisLAnG, M. Shaton, And M. Sicilian (2018): "The U.S. Syndicated Loan Market: Matching Data," Working paper.

Correa, R., L. S. Goldberg, and T. Rice (2015): "International Banking and Liquidity Risk Transmission: Evidence from the United States," IMF Economic Review, 63(3), 626643.

Correia, S. (2016): "Linear Models with High-Dimensional Fixed Effects: An Efficient and Feasible Estimator," Working paper, Duke University.

D’Amico, S., W. English, D. López-Salido, and E. Nelson (2012): "The Federal Reserve's Large-scale Asset Purchase Programmes: Rationale and Effects," Economic Journal, 122(564), F415-F446.

D'Amico, S., And T. B. King (2013): "Flow and Stock Effects of Large-Scale Treasury Purchases: Evidence on the Importance of Local Supply," Journal of Financial Economics, 108(2), 425-448.

Dell'Ariccia, G., L. Laeven, and R. Marquez (2014): "Real Interest Rates, Leverage, and Bank Risk-Taking," Journal of Economic Theory, 149, 65-99. 
Dell'Ariccia, G., L. Laeven, and G. A. Suarez (2017): "Bank Leverage and Monetary Policy's Risk-Taking Channel: Evidence from the United States," Journal of Finance, $72(2), 613-654$.

Di Maggio, M., And M. KacPerczyK (2017): "The Unintended Consequences of the Zero Lower Bound Policy," Journal of Financial Economics, 123(1), 59-80.

FAmA, E. F., And K. R. FREnCH (1997): "Industry Costs of Equity," Journal of Financial Economics, 43(2), 153-193.

Fishburn, P. C., And R. B. Porter (1976): "Optimal Portfolios with One Safe and One Risky Asset: Effects of Changes in Rate of Return and Risk," Management Science, 22(10), 1064-1073.

Ionnnidou, V., S. Ongena, And J. Peydro (2015): "Monetary Policy, Risk-Taking and Pricing: Evidence from a Quasi-Natural Experiment," Review of Finance, 19(1), 95-144.

Ivashina, V., And D. Scharfstein (2010a): "Bank Lending During the Financial Crisis of 2008," Journal of Financial Economics, 97(3), 319-338.

(2010b): "Loan Syndication and Credit Cycles," American Economic Review, $100(2), 57-61$.

Jimenez, G., S. Ongena, J. Peydro, and J. Saurina (2014): "Hazardous Times for Monetary Policy: What do Twenty-Three Million Bank Loans Say about the Effects of Monetary Policy on Credit-Risk Taking?," Econometrica, 82(2), 463-505.

Kalemli-Ozcan, S., B. Sorensen, and S. Yesiltas (2012): "Leverage across Firms, Banks, and Countries," Journal of International Economics, 88(2), 284-298.

Krishnamurthy, A., And A. Vissing-Jorgensen (2011): "The Effects of Quantitative Easing on Interest Rates: Channels and Implications for Policy," Brookings Papers on Economic Activity, Fall, 215-265.

Lee, S. J., L. Q. Liu, and V. Stebunovs (2017): "Risk Taking and Interest Rates: Evidence from Decades in the Global Syndicated Loan Market," International Finance Discussion Papers 1188, Board of Governors of the Federal Reserve System.

Londono, J. M. (2011): "The Variance Risk Premium around the World," International Finance Discussion Papers 1035, Board of Governors of the Federal Reserve System.

Merton, R. C. (1974): "On the Pricing of Corporate Debt: The Risk Structure of Interest Rates," Journal of Finance, 29(2), 449-470.

Morais, B., J.-L. Peydro, J. Roldan-Pena, and C. Ruiz-Ortega (2019): "The International Bank Lending Channel of Monetary Policy Rates and QE: Credit Supply, Reach-for-Yield, and Real Effects," Journal of Finance, 74(1), 55-90.

Murfin, J., And M. Petersen (2016): "Loans on Sale: Credit Market Seasonality, Borrower Need, and Lender Rents," Journal of Financial Economics, 121(2), 300-326.

Nazeran, P., And D. Dwyer (2015): "Credit Risk Modeling of Public Firms: EDF9," Discussion paper, Moody's Analytics. 
Petersen, M. A. (2009): "Estimating Standard Errors in Finance Panel Data Sets: Comparing Approaches," Review of Financial Studies, 22(1), 435-480.

Ratnovski, L., S. Claessens, and E. Cerutti (2017): "Global Liquidity and CrossBorder Bank Flows," Economic Policy, 32(89), 81-125.

Rey, H. (2015): "Dilemma not Trilemma: The global Financial Cycle and Monetary Policy Independence," Working Paper 21162, National Bureau of Economic Research.

Strahan, P. E. (1999): "Borrower Risk and the Price and Nonprice Terms of Bank Loans," FRBNY Staff Report 90, Federal Reserve Bank of New York.

Stulz, R. M. (2010): "Credit Default Swaps and the Credit Crisis," Journal of Economic Perspectives, 24(1), 73-92.

Temesvary, J., S. Ongena, And A. L. Owen (2018): "A Global Lending Channel Unplugged? Does U.S. Monetary Policy Affect Cross-Border and Affiliate Lending by Global U.S. Banks?," Journal of International Economics, 112, 50-69. 

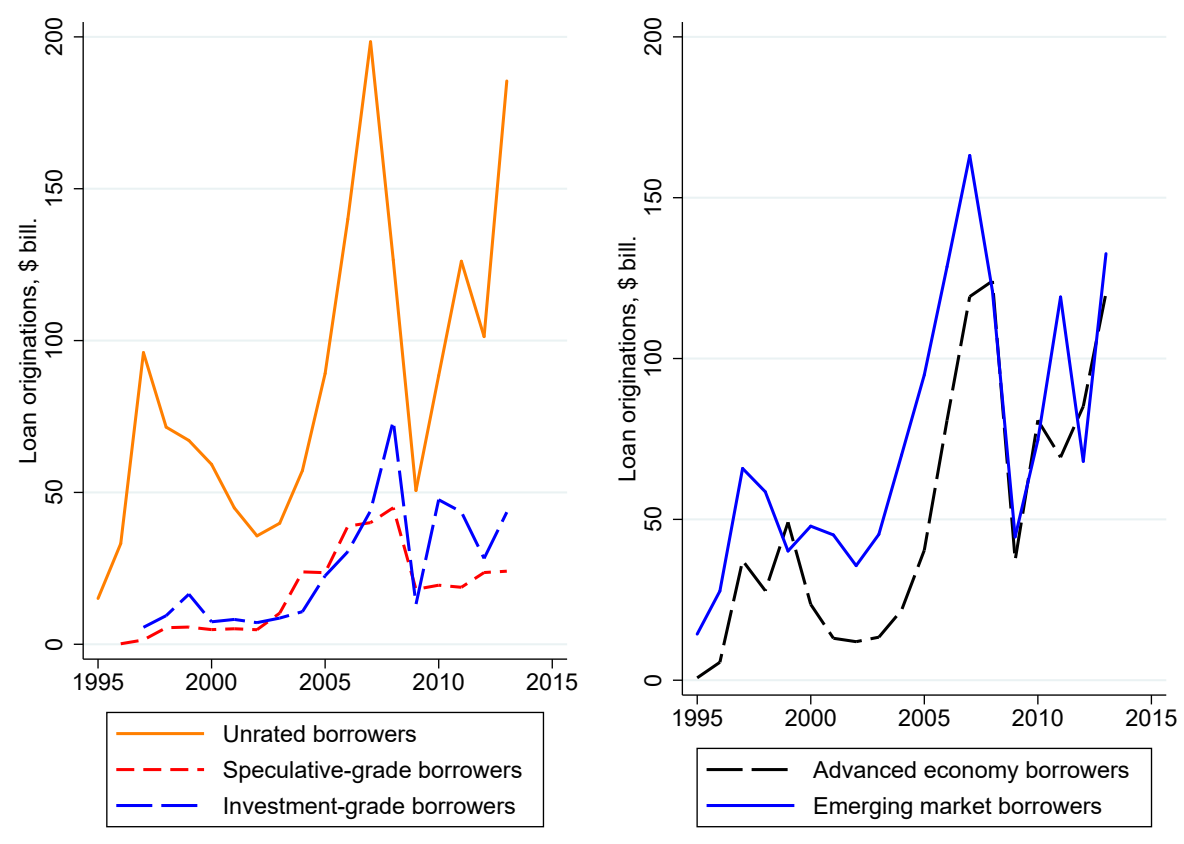

Figure 1: Originations of syndicated U.S. dollar term loans to non-U.S. borrowers

The figure is based on syndicated term loans that are denominated in U.S. dollars, indexed to the U.S. dollar Libor, and originated in the global market to non-U.S. borrowers (captured in the Refinitiv Loan Pricing Corporation (LPC) DealScan data). The majority of syndicated term loans are made to speculative-grade and unrated debt borrowers (left). Originations of syndicated term loans made to advanced economies and emerging markets' borrowers are similarly significant (right).

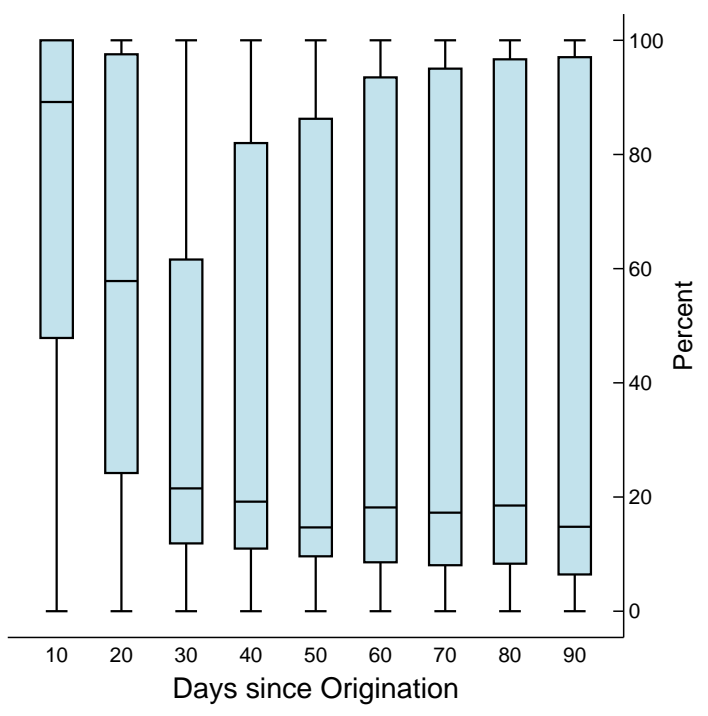

Figure 2: Bank shares in syndicated term loans at origination and over time

The figure is based on syndicated term loans originated in the United States (captured in the Shared National Credit data). It shows a sequence of box plots for bank-owned shares in syndicated term loans at loan origination and afterwards. The figure suggests that banks sell off their shares in loans to shadow banks - such as funds and structured products - quickly: The median of bank-owned shares in syndicated loans falls from 80 percent at origination to 20 percent within a month. Similar data for the global market are believed not to exist. 


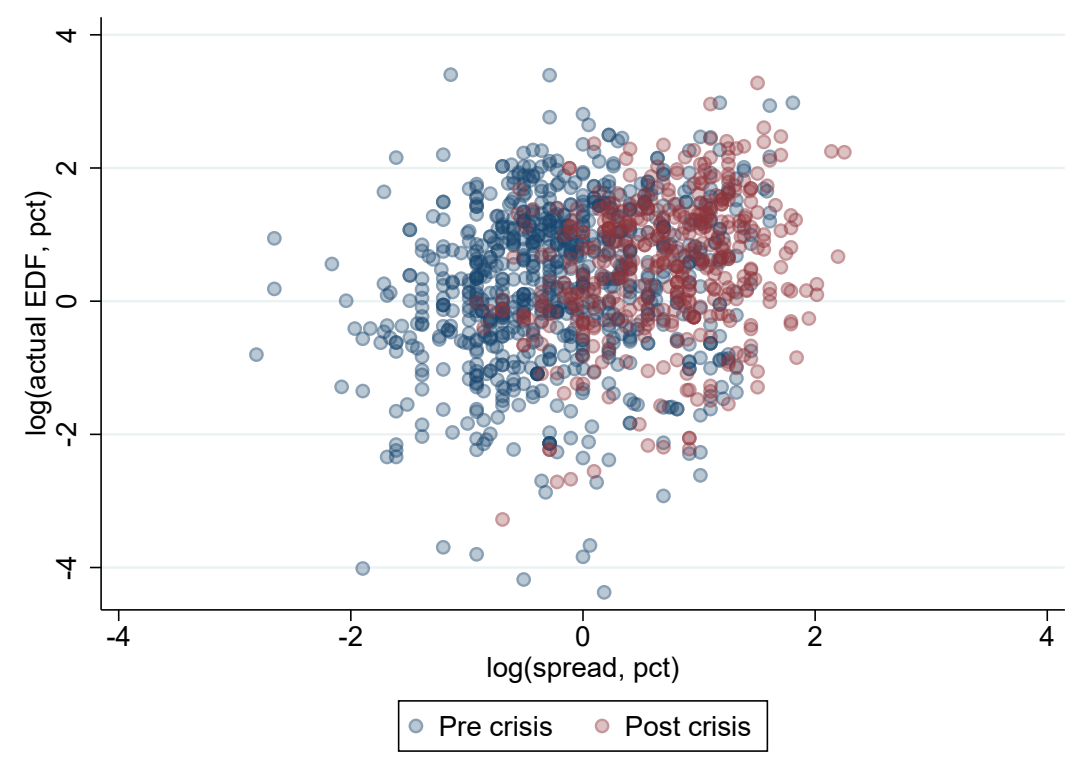

Figure 3: Loan spreads and EDFs

The figure is based on the merged Refinitiv Loan Pricing Corporation (LPC) DealScan and Moody's Analytics Credit Edge data. It shows that loan spreads and EDFs are highly positively correlated. The shift in the post-GFC period toward ex ante riskier loans that command higher loan spreads is evident.

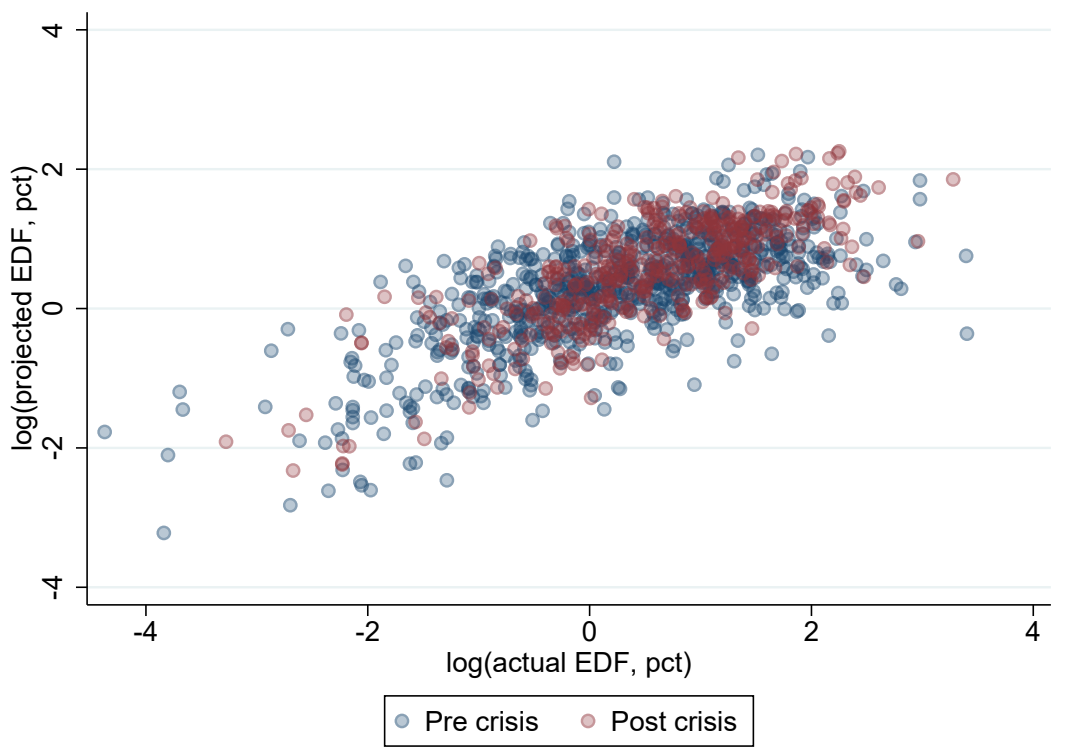

Figure 4: Actual and projected EDFs

The figure shows that actual EDFs and projected EDFs $(\widehat{E D F} \mathrm{~s})$ are highly positively correlated, so the goodness of fit is reassuringly high. Note, however, that equation 1 under-projects EDFs for riskier borrowers, which introduces a conservative bias in our analysis. 

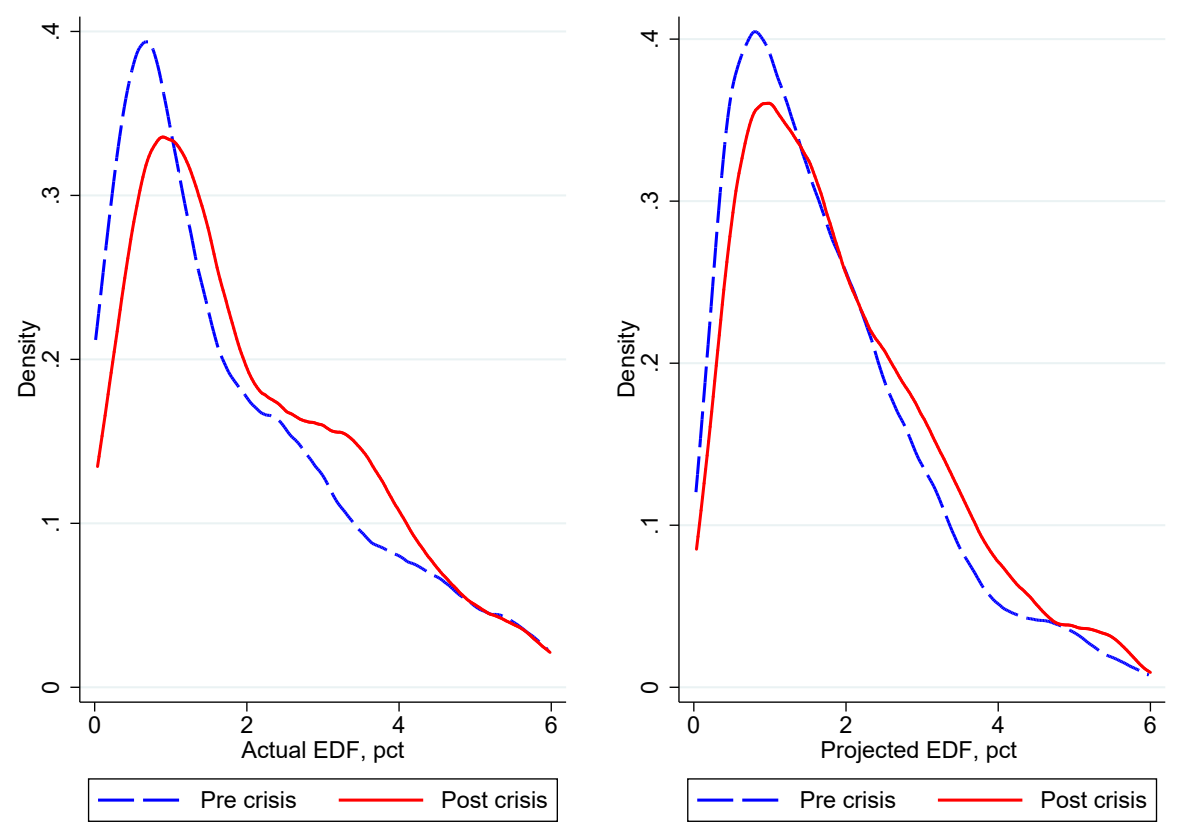

Figure 5: Densities of actual and projected EDFs

The figures shows two densities: One based on actual EDFs for a subset of borrowers in the DealScan data and one based on projected EDFs for all borrowers in the data. The two densities do not necessarily have to be identical, nevertheless, they paint a similar picture. Both densities show at a shift toward originations of ex ante riskier loans in the post-GFC period.
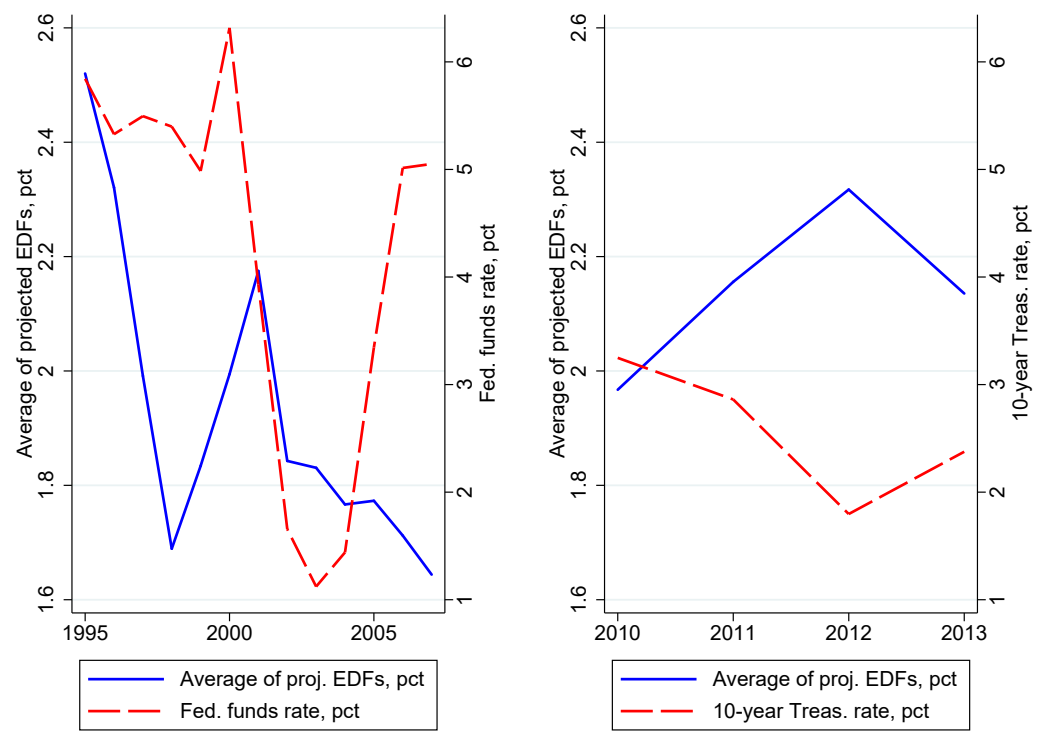

Figure 6: Averages of projected EDFs and U.S. interest rates

The figure shows the averages of projected EDFs and U.S. interest rates before (left) and after (right) the GFC. The negative correlation between the series is particularly striking in the post-GFC period. 
Table 1: Descriptive statistics for EDF projection model

\begin{tabular}{|c|c|c|c|c|c|c|}
\hline & Count & Median & & Pre-GFC period & Min & $\operatorname{Max}$ \\
\hline $\log ($ maturity-matched EDF, pct) & 794 & 0.36 & 0.29 & 1.15 & -4.37 & 3.40 \\
\hline $\log ($ spread, pct $)$ & 794 & -0.22 & -0.17 & 0.77 & -2.81 & 1.81 \\
\hline $\log ($ amount, $\$$ bill. $)$ & 794 & 18.42 & 18.34 & 1.19 & 14.35 & 22.86 \\
\hline \multirow[t]{2}{*}{$\log ($ duration, years) } & 794 & 1.61 & 1.32 & 0.64 & 0.00 & 3.00 \\
\hline & \multicolumn{6}{|c|}{ Post-GFC period } \\
\hline $\log$ (maturity-matched EDF, pct) & 433 & 0.62 & 0.55 & 1.00 & -3.28 & 3.28 \\
\hline $\log ($ spread, pct $)$ & 433 & 0.81 & 0.71 & 0.62 & -0.92 & 2.25 \\
\hline $\log ($ amount, $\$$ bill. $)$ & 433 & 19.11 & 18.98 & 1.23 & 14.91 & 23.25 \\
\hline $\log$ (duration, years) & 433 & 1.10 & 1.19 & 0.61 & 0.00 & 2.48 \\
\hline
\end{tabular}

Note. The sample is based on U.S. dollar, Libor indexed, non-U.S. borrower syndicated loans from Refinitiv LPC's DealScan matched to borrower EDFs from Moody's Analytics CreditEdge at the moment of loan origination. The horizons of EDFs are matched to the maturities of loans. The pre-GFC period is 1995:Q1 to 2007:Q2 and the post-GFC period is 2009:Q3 to 2014:Q4. 
Table 2: EDF projections for non-U.S. borrowers

\begin{tabular}{|c|c|c|}
\hline & $\begin{array}{c}(1) \\
\text { Pre-crisis }\end{array}$ & $\begin{array}{c}(2) \\
\text { Post-crisis }\end{array}$ \\
\hline $\log$ (loan spread, pct) & $\begin{array}{c}0.331^{* * *} \\
(2.926)\end{array}$ & $\begin{array}{c}0.375^{* * *} \\
(3.739)\end{array}$ \\
\hline $\log (\operatorname{loan}$ amount, $\$$ bill.) & $\begin{array}{c}-0.208^{* * *} \\
(-3.925)\end{array}$ & $\begin{array}{c}-0.058 \\
(-0.986)\end{array}$ \\
\hline $\log$ (loan maturity, years) & $\begin{array}{c}0.397^{* * *} \\
(5.337) \\
\end{array}$ & $\begin{array}{l}0.232^{*} \\
(1.791) \\
\end{array}$ \\
\hline Syndicate composition controls & $\mathrm{Y}$ & $\mathrm{Y}$ \\
\hline Secured loan fixed effects & $\mathrm{Y}$ & $\mathrm{Y}$ \\
\hline Loan purpose fixed effects & Y & Y \\
\hline Institution loan fixed effects & Y & $\mathrm{Y}$ \\
\hline Borrower country fixed effects & Y & $\mathrm{Y}$ \\
\hline Borrower industry fixed effects & Y & Y \\
\hline Borrower debt rating fixed effects & Y & $\mathrm{Y}$ \\
\hline Quarter fixed effects & $\mathrm{Y}$ & $\mathrm{Y}$ \\
\hline Num. of observ. & 794 & 433 \\
\hline R-sq. adj. & 0.41 & 0.52 \\
\hline R-sq. within. & 0.22 & 0.14 \\
\hline RMSE & 0.88 & 0.69 \\
\hline
\end{tabular}

Note. The regressions are based on U.S. dollar, Liborindexed, non-U.S. borrower loans from Refinitiv LPC's DealScan matched to borrower EDFs from Moody's Analytics CreditEdge. The dependent variable is a log of an EDF for a borrower in a given country and a given industry that got a syndicated loan in a given quarter, $\log \left(E D F_{j, b, t}\right)$. The horizon of the EDF is matched to the maturity of the loan. The separate estimation of the model for the pre- and post-GFC periods allows for structural breaks in regression coefficients, including fixed effects. Syndicate composition controls include the presence of nonbank lenders and the number of lenders in the syndicate. Loan purpose fixed effects include LBO, takeover, and corporate purposes dummies. Borrower industry fixed effects are based on the Fama and French classification of 38 industries. Borrower debt rating fixed effects are nonrated and speculative grade dummies. As the comparison of adjusted R-squareds and within $\mathrm{R}$-squareds suggests, borrower-related fixed effects account for a significant share of the explained variation. Inclusion of additional loan or borrower characteristics improves the goodness of fit only marginally but limits the number of loans for which we can project EDFs. Errors are clustered by quarter, borrower country, and borrower industry. The pre-GFC period is 1995:Q1 to 2007:Q2 and the post-GFC period is 2009:Q3 to 2014:Q4. 
Table 3: Countries of borrowers in the loan- and portfolio analyses

\begin{tabular}{lc}
\hline \hline Advanced economies & Emerging markets \\
\hline Australia & Brazil \\
Belgium & Chile \\
Canada & Czech Republic \\
Denmark & Hong Kong \\
Finland & Hungary \\
France & Indonesia \\
Germany & Malaysia \\
Greece & Mexico \\
Ireland & Philippenes \\
Italy & Poland \\
Japan & Russia \\
Netherlands & Singapore \\
New Zealand & South Africa \\
Norway & Thailand \\
Portugal & Turkey \\
Spain & \\
Sweden & \\
Switzerland & \\
United Kingdom & \\
\hline Note. Borrowers from the listed \\
countries are in the samples that are \\
used in the loan- and portfolio-level \\
analyses.
\end{tabular}

Table 4: Descriptive statistics for projected EDFs and select global and local factors in loan-level regressions

\begin{tabular}{|c|c|c|c|c|c|}
\hline & Median & Mean & Std. dev & Min & Max \\
\hline & \multicolumn{5}{|c|}{ Pre-GFC period } \\
\hline $\log ($ projected EDF, pct) & 0.19 & 0.09 & 0.98 & -3.57 & 3.17 \\
\hline Fed. funds rate, pct & 5.18 & 4.17 & 1.82 & 1.00 & 6.53 \\
\hline 10-year U.S. Treas. rate, pct & 5.35 & 5.42 & 0.93 & 3.80 & 7.57 \\
\hline Conditional variance & 1.91 & 3.00 & 2.48 & 0.54 & 12.41 \\
\hline Variance risk premium & 1.08 & 1.37 & 1.03 & -0.94 & 3.98 \\
\hline European sovereign spread, pct & 0.26 & 0.97 & 1.58 & 0.12 & 5.78 \\
\hline Expected inflation, pct & 2.87 & 2.84 & 0.41 & 1.07 & 3.67 \\
\hline Low-grade bond spread, pct & 3.78 & 4.65 & 1.77 & 2.76 & 8.89 \\
\hline News-based uncertainty index & 84.64 & 95.40 & 32.48 & 52.09 & 190.67 \\
\hline Borr. country group U.S. dollar exch. rate $_{g}$ & 114.83 & 112.37 & 10.20 & 90.20 & 129.18 \\
\hline Borr. country realized volatility ${ }_{c}$ & 19.49 & 21.95 & 13.31 & 7.81 & 86.01 \\
\hline Borr. country RGDP growth $_{c}$, pct & 4.86 & 4.60 & 2.61 & -0.59 & 9.56 \\
\hline \multirow[t]{2}{*}{ Borr. country short-term rate $_{c}$, pct } & 7.50 & 11.55 & 13.24 & 1.48 & 89.94 \\
\hline & \multicolumn{5}{|c|}{ Post-GFC period } \\
\hline $\log ($ projected EDF, pct) & 0.22 & 0.17 & 0.84 & -3.35 & 2.41 \\
\hline 10-year U.S. Treas. rate, pct & 2.77 & 2.72 & 0.78 & 1.64 & 3.87 \\
\hline Conditional variance & 1.71 & 3.02 & 2.66 & 1.14 & 10.62 \\
\hline Variance risk premium & 1.70 & 1.45 & 0.82 & -0.48 & 2.98 \\
\hline European sovereign spread, pct & 2.48 & 2.44 & 1.24 & 0.82 & 4.43 \\
\hline Expected inflation, pct & 3.12 & 3.14 & 0.41 & 2.54 & 4.17 \\
\hline Low-grade bond spread, pct & 5.17 & 5.24 & 1.12 & 3.62 & 8.04 \\
\hline News-based uncertainty index & 138.58 & 144.82 & 33.61 & 98.14 & 235.08 \\
\hline Borr. country group U.S. dollar exch. rate $_{g}$ & 100.63 & 100.20 & 2.30 & 95.28 & 103.57 \\
\hline Borr. country realized volatility ${ }_{c}$ & 17.53 & 17.96 & 6.66 & 6.95 & 35.76 \\
\hline Borr. country RGDP growth , pct & 1.74 & 1.79 & 3.29 & -7.81 & 6.35 \\
\hline Borr. country short-term rate $_{c}$, pct & 0.57 & 2.82 & 3.31 & 0.18 & 8.75 \\
\hline Borr. country 10 -year sovereign rate $_{c}$, pct & 3.19 & 3.86 & 2.50 & 0.75 & 9.18 \\
\hline
\end{tabular}


Table 5: Loan-level regressions: U.S. and non-U.S. lenders

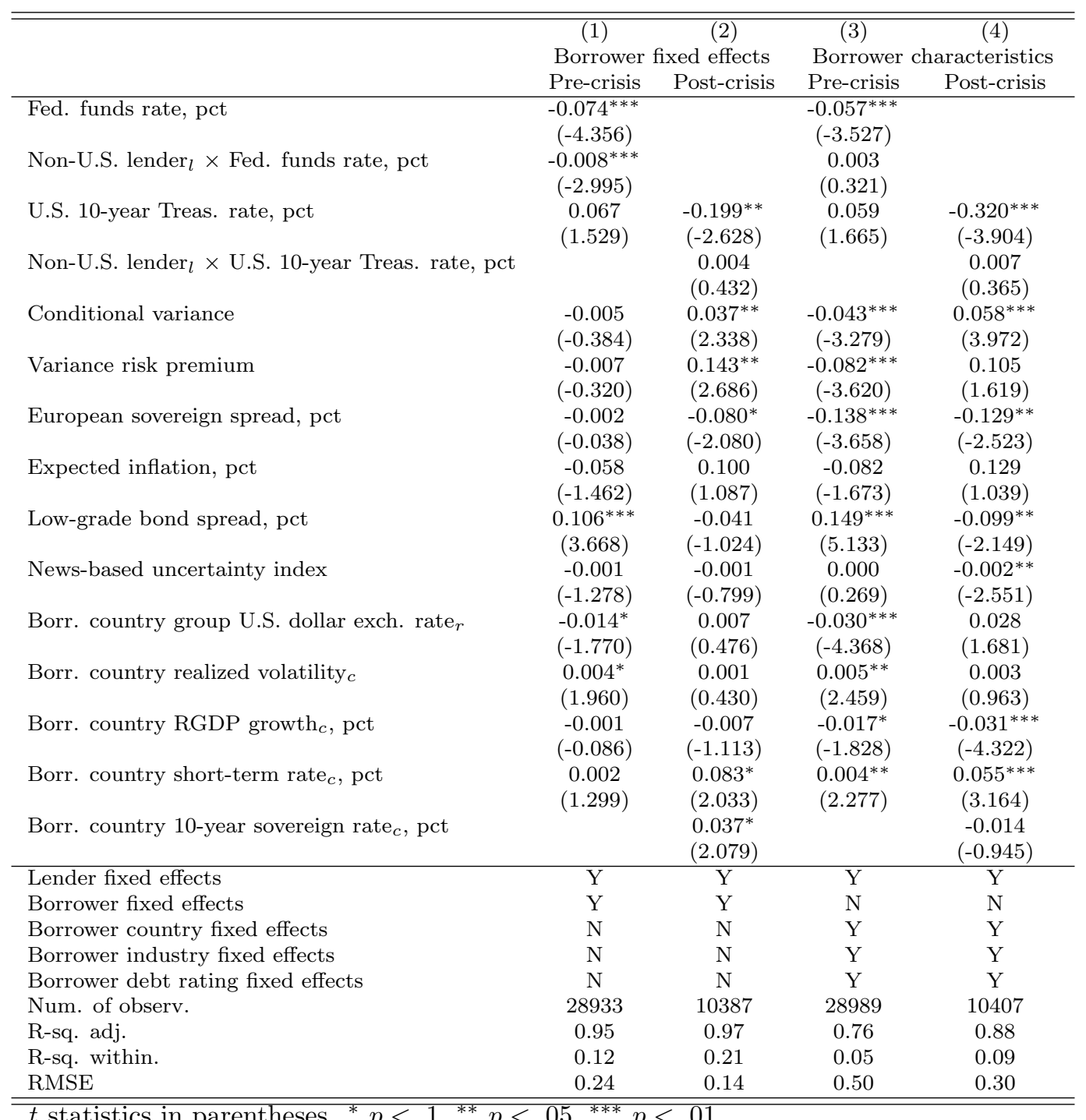

$t$ statistics in parentheses. ${ }^{*} p<.1,{ }^{* *} p<.05,{ }^{* * *} p<.01$.

Note. The dependent variable is a log of projected EDF for the borrower of a given loan. Because a loan may have multiple lenders, it may appear multiple times in the estimation. The variable non-U.S. lender dummy $l$ is a dummy that is equal to 1 if lender $l$ is a non-U.S. institution. Borrower industry fixed effects are based on the Fama and French classification of 38 industries. Borrower debt rating fixed effects include nonrated and speculative grade dummies. Errors are clustered by quarter, lender, and syndicate. 
Table 6: General marginal effects based on loan-level regressions for U.S. and non-U.S. lenders

\begin{tabular}{|c|c|c|}
\hline \multirow[b]{2}{*}{ Factor } & \multicolumn{2}{|c|}{$\begin{array}{c}\text { Marginal effects from one standard deviation } \\
\text { decrease in a factor, basis points }\end{array}$} \\
\hline & Pre-GFC period & Post-GFC period \\
\hline Federal funds rate & 14 & \\
\hline U.S. 10-year Treasury rate & & 24 \\
\hline Borr. country group U.S. dollar exch. rate & 25 & \\
\hline Low-grade bond spread & -25 & \\
\hline Borr. country realized volatility & -7 & \\
\hline Conditional variance & & -15 \\
\hline European sovereign spread & & 31 \\
\hline
\end{tabular}

Note. Based on the results in table 5. Marginal effects are constructed using the averages of the estimated coefficients across the specifications around the sample averages of projected EDFs (because equation 2 is a semi-log model). These sample averages do not differentiate the riskiness of loans originated by U.S. and non-U.S. lenders. Only statistically significant general marginal effects are shown. Cross-sectional marginal effects of U.S. monetary policy are not considered because they are mostly statistically insignificant. 
Table 7: Loan-level regressions: Bank and nonbank lenders

\begin{tabular}{|c|c|c|c|c|}
\hline & \multirow{2}{*}{\multicolumn{2}{|c|}{$\begin{array}{cc}(1) & (2) \\
\text { Borrower fixed effects }\end{array}$}} & \multirow{2}{*}{\multicolumn{2}{|c|}{$\begin{array}{cc}(3) & (4) \\
\text { Borrower characteristics }\end{array}$}} \\
\hline & & & & \\
\hline & Pre-crisis & Post-crisis & Pre-crisis & Post-crisis \\
\hline Fed. funds rate, pct & $\begin{array}{c}-0.082^{* * *} \\
(-4.689)\end{array}$ & & $\begin{array}{c}-0.055^{* * *} \\
(-3.510)\end{array}$ & \\
\hline Nonbank lender ${ }_{i} \times$ Fed. funds rate, pct & $\begin{array}{c}0.004 \\
(1.508)\end{array}$ & & $\begin{array}{l}0.005 \\
(0.705)\end{array}$ & \\
\hline U.S. 10-year Treas. rate, pct & $\begin{array}{l}0.067 \\
(1.529)\end{array}$ & $\begin{array}{r}-0.195^{* *} \\
(-2.494)\end{array}$ & $\begin{array}{c}0.059 \\
(1.668)\end{array}$ & $\begin{array}{c}-0.309^{* * *} \\
(-3.803)\end{array}$ \\
\hline Nonbank lender $i \times$ U.S. 10-year Treas. rate, pct & & $\begin{array}{c}-0.016^{* * *} \\
(-2.917)\end{array}$ & & $\begin{array}{r}-0.026^{* *} \\
(-2.693)\end{array}$ \\
\hline Conditional variance & $\begin{array}{l}-0.005 \\
(-0.383)\end{array}$ & $\begin{array}{r}0.037^{* *} \\
(2.334)\end{array}$ & $\begin{array}{c}-0.043^{* * *} \\
(-3.271)\end{array}$ & $\begin{array}{c}0.058^{* * *} \\
(3.921)\end{array}$ \\
\hline Variance risk premium & $\begin{array}{l}-0.007 \\
(-0.315)\end{array}$ & $\begin{array}{l}0.143^{* *} \\
(2.684)\end{array}$ & $\begin{array}{c}-0.082^{* * *} \\
(-3.618)\end{array}$ & $\begin{array}{l}0.105 \\
(1.620)\end{array}$ \\
\hline European sovereign spread, pct & $\begin{array}{l}-0.001 \\
(-0.029)\end{array}$ & $\begin{array}{l}-0.081^{*} \\
(-2.098)\end{array}$ & $\begin{array}{c}-0.138^{* * *} \\
(-3.657)\end{array}$ & $\begin{array}{r}-0.128^{* *} \\
(-2.514)\end{array}$ \\
\hline Expected inflation, pct & $\begin{array}{l}-0.058 \\
(-1.449)\end{array}$ & $\begin{array}{c}0.101 \\
(1.095)\end{array}$ & $\begin{array}{c}-0.082 \\
(-1.672)\end{array}$ & $\begin{array}{c}0.128 \\
(1.033)\end{array}$ \\
\hline Low-grade bond spread, pct & $\begin{array}{c}0.106^{* * *} \\
(3.670)\end{array}$ & $\begin{array}{c}-0.041 \\
(-1.026)\end{array}$ & $\begin{array}{c}0.149^{* * *} \\
(5.119)\end{array}$ & $\begin{array}{c}-0.099^{* *} \\
(-2.144)\end{array}$ \\
\hline News-based uncertainty index & $\begin{array}{c}-0.001 \\
(-1.287)\end{array}$ & $\begin{array}{c}-0.001 \\
(-0.833)\end{array}$ & $\begin{array}{c}0.000 \\
(0.271)\end{array}$ & $\begin{array}{c}-0.002^{* *} \\
(-2.547)\end{array}$ \\
\hline Borr. country group U.S. dollar exch. rate $_{r}$ & $\begin{array}{l}-0.014^{*} \\
(-1.762)\end{array}$ & $\begin{array}{c}0.007 \\
(0.481)\end{array}$ & $\begin{array}{c}-0.030^{* * *} \\
(-4.363)\end{array}$ & $\begin{array}{c}0.028 \\
(1.671)\end{array}$ \\
\hline Borr. country realized volatility ${ }_{c}$ & $\begin{array}{l}0.004^{*} \\
(1.968)\end{array}$ & $\begin{array}{c}0.001 \\
(0.427)\end{array}$ & $\begin{array}{c}0.005^{* *} \\
(2.455)\end{array}$ & $\begin{array}{c}0.003 \\
(0.954)\end{array}$ \\
\hline Borr. country RGDP growth ${ }_{c}$, pct & $\begin{array}{l}-0.000 \\
(-0.073)\end{array}$ & $\begin{array}{c}-0.007 \\
(-1.117)\end{array}$ & $\begin{array}{l}-0.018^{*} \\
(-1.826)\end{array}$ & $\begin{array}{c}-0.031^{* * *} \\
(-4.255)\end{array}$ \\
\hline Borr. country short-term rate ${ }_{c}$, pct & $\begin{array}{c}0.002 \\
(1.303)\end{array}$ & $\begin{array}{l}0.083^{*} \\
(2.030)\end{array}$ & $\begin{array}{c}0.004^{* *} \\
(2.280)\end{array}$ & $\begin{array}{c}0.055^{* * *} \\
(3.155)\end{array}$ \\
\hline Borr. country 10-year sovereign rate ${ }_{c}$, pct & & $\begin{array}{l}0.038^{*} \\
(2.099)\end{array}$ & & $\begin{array}{c}-0.014 \\
(-0.927) \\
\end{array}$ \\
\hline Lender fixed effects & $\mathrm{Y}$ & $\mathrm{Y}$ & $\mathrm{Y}$ & $\mathrm{Y}$ \\
\hline Borrower fixed effects & $\mathrm{Y}$ & $\mathrm{Y}$ & $\mathrm{N}$ & $\mathrm{N}$ \\
\hline Borrower country fixed effects & $\mathrm{N}$ & $\mathrm{N}$ & $\mathrm{Y}$ & $\mathrm{Y}$ \\
\hline Borrower industry fixed effects & $\mathrm{N}$ & $\mathrm{N}$ & $\mathrm{Y}$ & $\mathrm{Y}$ \\
\hline Borrower debt rating fixed effects & $\mathrm{N}$ & $\mathrm{N}$ & $\mathrm{Y}$ & $\mathrm{Y}$ \\
\hline Num. of observ. & 28933 & 10387 & 28989 & 10407 \\
\hline R-sq. adj. & 0.95 & 0.97 & 0.76 & 0.88 \\
\hline R-sq. within. & 0.12 & 0.21 & 0.05 & 0.09 \\
\hline RMSE & 0.24 & 0.14 & 0.50 & 0.30 \\
\hline
\end{tabular}

$t$ statistics in parentheses. ${ }^{*} p<.1,{ }^{* *} p<.05,{ }^{* * *} p<.01$.

Note. The dependent variable is a projected EDF for the borrower of a given loan.

Because a loan may have multiple lenders, it may appear multiple times in the estimation.

Nonbank lenders are identified based on their SIC codes. Borrower industry fixed effects are based on the Fama and French classification of 38 industries. Borrower debt rating fixed effects include nonrated and speculative grade dummies. Errors are clustered by quarter, lender, and syndicate. 
Table 8: Descriptive statistics for projected EDFs in portfolio-level regressions

\begin{tabular}{lcccccc}
\hline \hline Loan portfolios & Num. of obs. & Median & Mean & Std. dev. & Min & Max \\
& 3410 & -0.22 & -0.28 & 0.65 & -2.87 & 1.59 \\
& Pre-crisis: $\log ($ projected EDF, pct) & \\
\hline Advanced economies & 3410 & 0.28 & 0.21 & 0.72 & -2.68 & 3.17 \\
Emerging markets & 5603 & \multicolumn{7}{c}{ Post-crisis: $\log$ (projected EDF, pct) } \\
\hline & 1387 & 0.19 & 0.09 & 0.83 & -3.33 & 2.11 \\
\hline Advanced economies & 2064 & 0.33 & 0.30 & 0.57 & -2.26 & 2.41 \\
\hline Emerging markets &
\end{tabular}

Note. The summary statistics are for a log of the simple average of projected EDFs of borrowers in loan portfolio $g$ of lender $l$. The precrisis period is 1995:Q1 to 2007:Q2 and the post-crisis period is 2009:Q3 to 2014:Q4. 
Table 9: Portfolio-level regressions: U.S. and non-U.S. lenders

\begin{tabular}{|c|c|c|}
\hline & $\begin{array}{c}(1) \\
\text { Pre-crisis }\end{array}$ & $\begin{array}{c}(2) \\
\text { Post-crisis }\end{array}$ \\
\hline Fed. funds rate, pct & $\begin{array}{c}-0.069^{* * *} \\
(-3.201)\end{array}$ & \\
\hline Non-U.S. lender $l \times$ Fed. funds rate, pct & $\begin{array}{l}0.025^{* *} \\
(2.183)\end{array}$ & \\
\hline U.S. 10-year Treas. rate, pct & $\begin{array}{l}0.122^{* *} \\
(2.245)\end{array}$ & $\begin{array}{l}-0.185^{*} \\
(-1.817)\end{array}$ \\
\hline Non-U.S. lender $l$ × U.S. 10-year Treas. rate, pct & & $\begin{array}{r}-0.100^{* *} \\
(-2.400)\end{array}$ \\
\hline Conditional variance & $\begin{array}{l}-0.017 \\
(-1.035)\end{array}$ & $\begin{array}{l}0.086^{* *} \\
(2.895)\end{array}$ \\
\hline Variance risk premium & $\begin{array}{l}-0.051 \\
(-1.288)\end{array}$ & $\begin{array}{c}0.073 \\
(0.922)\end{array}$ \\
\hline European sovereign spread, pct & $\begin{array}{l}-0.029 \\
(-0.575)\end{array}$ & $\begin{array}{l}-0.117 \\
(-1.550)\end{array}$ \\
\hline Expected inflation, pct & $\begin{array}{c}0.030 \\
(0.408)\end{array}$ & $\begin{array}{l}-0.064 \\
(-0.566)\end{array}$ \\
\hline Low-grade bond spread, pct & $\begin{array}{l}0.096^{* *} \\
(2.500)\end{array}$ & $\begin{array}{c}-0.061 \\
(-1.392)\end{array}$ \\
\hline News-based uncertainty index & $\begin{array}{c}0.002 \\
(1.081)\end{array}$ & $\begin{array}{c}-0.007^{* * *} \\
(-4.023)\end{array}$ \\
\hline Borr. country group U.S. dollar exch. rate $_{l, g}$ & $\begin{array}{l}-0.021^{*} \\
(-1.863)\end{array}$ & $\begin{array}{l}-0.015 \\
(-0.870)\end{array}$ \\
\hline Borr. country realized volatility $l, g$ & $\begin{array}{c}0.001 \\
(0.187)\end{array}$ & $\begin{array}{l}-0.003 \\
(-0.350)\end{array}$ \\
\hline Borr. country RGDP growth g $_{l, g}$, pct & $\begin{array}{l}-0.025^{*} \\
(-1.901)\end{array}$ & $\begin{array}{c}0.004 \\
(0.331)\end{array}$ \\
\hline Borr. country short-term rate $_{l, g}$, pct & $\begin{array}{c}0.010^{* * *} \\
(3.646)\end{array}$ & $\begin{array}{c}-0.018 \\
(-1.148)\end{array}$ \\
\hline Borr. country 10-year sovereign rate $_{l, g}$, pct & & $\begin{array}{c}0.010 \\
(0.576) \\
\end{array}$ \\
\hline Lender fixed effects & $\mathrm{Y}$ & $\mathrm{Y}$ \\
\hline Portofolio region fixed effects & $\mathrm{Y}$ & $\mathrm{Y}$ \\
\hline Num. of observ. & 9013 & 3451 \\
\hline R-sq. adj. & 0.33 & 0.33 \\
\hline R-sq. within. & 0.08 & 0.07 \\
\hline RMSE & 0.60 & 0.57 \\
\hline \multicolumn{3}{|c|}{$\begin{array}{l}t \text { statistics in parentheses. }{ }^{*} p<.1,{ }^{* *} p<.05,{ }^{* * *} p<.01 \text {. } \\
\text { Note. The dependent variable is the simple average of projected } \\
\text { EDFs for borrowers in loan portfolio } g \text { of lender } l \text {. The variable } \\
\text { non-U.S. lender }{ }_{l} \text { is a dummy that is equal to } 1 \text { if lender } l \text { is a } \\
\text { non-U.S. institution. Errors are clustered by quarter and lender. }\end{array}$} \\
\hline
\end{tabular}


Table 10: Portfolio-level regressions: Bank and nonbank lenders

\begin{tabular}{|c|c|c|c|c|}
\hline & \multirow{2}{*}{\multicolumn{2}{|c|}{$\begin{array}{l}(2) \\
\text { All lenders }\end{array}$}} & \multicolumn{2}{|c|}{$(3) \quad(4)$} \\
\hline & & & Non-U & lenders \\
\hline & Pre-crisis & Post-crisis & Pre-crisis & Post-crisis \\
\hline Fed. funds rate, pct & $\begin{array}{c}-0.046^{* *} \\
(-2.255)\end{array}$ & & $\begin{array}{c}-0.045^{* *} \\
(-2.183)\end{array}$ & \\
\hline Nonbank lender $_{i} \times$ Fed. funds rate, pct & $\begin{array}{l}-0.004 \\
(-0.219)\end{array}$ & & $\begin{array}{l}-0.006 \\
(-0.336)\end{array}$ & \\
\hline U.S. 10-year Treas. rate, pct & $\begin{array}{l}0.122^{* *} \\
(2.244)\end{array}$ & $\begin{array}{l}-0.268^{* *} \\
(-2.613)\end{array}$ & $\begin{array}{l}0.124^{* *} \\
(2.373)\end{array}$ & $\begin{array}{r}-0.289^{* *} \\
(-2.715)\end{array}$ \\
\hline Nonbank lender $_{i} \times$ U.S. 10-year Treas. rate, pct & & $\begin{array}{l}-0.054 \\
(-1.163)\end{array}$ & & $\begin{array}{l}-0.100^{*} \\
(-1.879)\end{array}$ \\
\hline Conditional variance & $\begin{array}{l}-0.017 \\
(-1.036)\end{array}$ & $\begin{array}{c}0.087^{* * *} \\
(2.913)\end{array}$ & $\begin{array}{l}-0.018 \\
(-1.151)\end{array}$ & $\begin{array}{l}0.092^{* *} \\
(2.872)\end{array}$ \\
\hline Variance risk premium & $\begin{array}{l}-0.051 \\
(-1.291)\end{array}$ & $\begin{array}{c}0.075 \\
(0.944)\end{array}$ & $\begin{array}{l}-0.045 \\
(-1.205)\end{array}$ & $\begin{array}{c}0.080 \\
(0.958)\end{array}$ \\
\hline European sovereign spread, pct & $\begin{array}{l}-0.029 \\
(-0.574)\end{array}$ & $\begin{array}{l}-0.118 \\
(-1.557)\end{array}$ & $\begin{array}{l}-0.037 \\
(-0.743)\end{array}$ & $\begin{array}{l}-0.118 \\
(-1.474)\end{array}$ \\
\hline Expected inflation, pct & $\begin{array}{c}0.030 \\
(0.404)\end{array}$ & $\begin{array}{l}-0.062 \\
(-0.551)\end{array}$ & $\begin{array}{c}0.005 \\
(0.072)\end{array}$ & $\begin{array}{c}-0.099 \\
(-0.819)\end{array}$ \\
\hline Low-grade bond spread, pct & $\begin{array}{l}0.096^{* *} \\
(2.487)\end{array}$ & $\begin{array}{c}-0.063 \\
(-1.441)\end{array}$ & $\begin{array}{c}0.106^{* * * *} \\
(2.736)\end{array}$ & $\begin{array}{c}-0.065 \\
(-1.431)\end{array}$ \\
\hline News-based uncertainty index & $\begin{array}{c}0.002 \\
(1.081)\end{array}$ & $\begin{array}{c}-0.007^{* * *} \\
(-3.995)\end{array}$ & $\begin{array}{c}0.002 \\
(1.012)\end{array}$ & $\begin{array}{c}-0.008^{* * *} \\
(-3.988)\end{array}$ \\
\hline Borr. country group U.S. dollar exch. rate $_{l, g}$ & $\begin{array}{l}-0.021^{*} \\
(-1.862)\end{array}$ & $\begin{array}{l}-0.015 \\
-0.868)\end{array}$ & $\begin{array}{c}-0.023^{* *} \\
(-2.053)\end{array}$ & $\begin{array}{l}-0.022 \\
(-1.165)\end{array}$ \\
\hline Borr. country realized volatility $l, g$ & $\begin{array}{c}0.000 \\
(0.176)\end{array}$ & $\begin{array}{c}-0.003 \\
(-0.335)\end{array}$ & $\begin{array}{c}0.001 \\
(0.290)\end{array}$ & $\begin{array}{c}-0.003 \\
(-0.287)\end{array}$ \\
\hline Borr. country RGDP growth $l, g$, pct & $\begin{array}{l}-0.025^{*} \\
(-1.919)\end{array}$ & $\begin{array}{c}0.004 \\
(0.314)\end{array}$ & $\begin{array}{l}-0.022 \\
(-1.669)\end{array}$ & $\begin{array}{c}0.006 \\
(0.479)\end{array}$ \\
\hline Borr. country short-term rate $_{l, g}$, pct & $\begin{array}{c}0.010^{* * *} \\
(3.631)\end{array}$ & $\begin{array}{c}-0.018 \\
(-1.168)\end{array}$ & $\begin{array}{c}0.010^{* * *} \\
(3.414)\end{array}$ & $\begin{array}{c}-0.014 \\
(-0.910)\end{array}$ \\
\hline Borr. country 10-year sovereign rate $_{l, g}$, pct & & $\begin{array}{c}0.011 \\
(0.609) \\
\end{array}$ & & $\begin{array}{c}0.006 \\
(0.312) \\
\end{array}$ \\
\hline Lender fixed effects & $\mathrm{Y}$ & $\mathrm{Y}$ & $\mathrm{Y}$ & $\mathrm{Y}$ \\
\hline Portofolio region fixed effects & Y & $\mathrm{Y}$ & $\mathrm{Y}$ & $\mathrm{Y}$ \\
\hline Num. of observ. & 9013 & 3451 & 8157 & 3037 \\
\hline R-sq. adj. & 0.33 & 0.33 & 0.33 & 0.31 \\
\hline R-sq. within. & 0.08 & 0.07 & 0.07 & 0.07 \\
\hline RMSE & 0.60 & 0.57 & 0.60 & 0.58 \\
\hline
\end{tabular}

$t$ statistics in parentheses. ${ }^{*} p<.1,{ }^{* *} p<.05,{ }^{* * *} p<.01$.

Note. The dependent variable is the simple average of projected EDFs for borrowers in loan portfolio $g$ of lender $l$. Nonbank lenders are identified based on their SIC codes. Errors are clustered by quarter and lender. 
Table 11: Portfolio-level regressions: U.S. and non-U.S. lender capitalization

\begin{tabular}{|c|c|c|c|c|}
\hline & (1) & $(2)$ & $(3)$ & $(4)$ \\
\hline & \multicolumn{2}{|c|}{ Country-level capital ratios } & \multicolumn{2}{|c|}{ Bank-level capital ratios } \\
\hline & All lenders & Non-U.S. lenders & All banks & Non-U.S. banks \\
\hline U.S. 10-year Treas. rate, pct & $\begin{array}{c}-0.377^{* * *} \\
(-2.905)\end{array}$ & $\begin{array}{c}-0.471^{* * *} \\
(-3.353)\end{array}$ & $\begin{array}{l}-0.402^{*} \\
(-1.942)\end{array}$ & $\begin{array}{l}-0.428^{*} \\
(-2.086)\end{array}$ \\
\hline Low capitalization $l \times$ U.S. 10 -year Treas. rate, pct & $\begin{array}{l}0.099^{*} \\
(2.012)\end{array}$ & $\begin{array}{l}0.144^{* *} \\
(2.720)\end{array}$ & $\begin{array}{c}0.209^{* * *} \\
(3.495)\end{array}$ & $\begin{array}{l}0.195^{* *} \\
(2.848)\end{array}$ \\
\hline Low capitalization $l$ & $\begin{array}{l}-0.205 \\
(-1.413)\end{array}$ & $\begin{array}{l}-0.363^{* *} \\
(-2.245)\end{array}$ & $\begin{array}{c}-0.618^{* * *} \\
(-2.981)\end{array}$ & $\begin{array}{l}-0.541^{* *} \\
(-2.525)\end{array}$ \\
\hline Conditional variance & $\begin{array}{c}0.101^{* * *} \\
(2.994)\end{array}$ & $\begin{array}{c}0.119^{* * *} \\
(3.221)\end{array}$ & $\begin{array}{l}0.099^{*} \\
(1.768)\end{array}$ & $\begin{array}{l}0.099^{*} \\
(1.745)\end{array}$ \\
\hline Variance risk premium & $\begin{array}{c}0.117 \\
(1.309)\end{array}$ & $\begin{array}{c}0.146 \\
(1.566)\end{array}$ & $\begin{array}{c}0.049 \\
(0.303)\end{array}$ & $\begin{array}{c}0.069 \\
(0.438)\end{array}$ \\
\hline European sovereign spread, pct & $\begin{array}{l}-0.133 \\
(-1.572)\end{array}$ & $\begin{array}{l}-0.138 \\
(-1.510)\end{array}$ & $\begin{array}{l}-0.193 \\
(-1.444)\end{array}$ & $\begin{array}{l}-0.194 \\
(-1.426)\end{array}$ \\
\hline Expected inflation, pct & $\begin{array}{c}0.011 \\
(0.074)\end{array}$ & $\begin{array}{l}-0.063 \\
(-0.422)\end{array}$ & $\begin{array}{l}-0.050 \\
(-0.251)\end{array}$ & $\begin{array}{c}-0.086 \\
(-0.443)\end{array}$ \\
\hline Low-grade bond spread, pct & $\begin{array}{c}-0.070 \\
(-1.383)\end{array}$ & $\begin{array}{l}-0.090^{*} \\
(-1.762)\end{array}$ & $\begin{array}{c}-0.083 \\
(-0.934)\end{array}$ & $\begin{array}{c}-0.091 \\
(-1.004)\end{array}$ \\
\hline News-based uncertainty index & $\begin{array}{c}-0.007^{* * *} \\
(-3.552)\end{array}$ & $\begin{array}{c}-0.009^{* * *} \\
(-3.840)\end{array}$ & $\begin{array}{c}-0.007^{* *} \\
(-2.537)\end{array}$ & $\begin{array}{c}-0.008^{* *} \\
(-2.656)\end{array}$ \\
\hline Borr. region U.S. dollar exch. rate r $_{l, g}$ & $\begin{array}{c}-0.014 \\
(-0.556)\end{array}$ & $\begin{array}{c}-0.029 \\
(-1.159)\end{array}$ & $\begin{array}{c}0.011 \\
(0.319)\end{array}$ & $\begin{array}{c}0.001 \\
(0.027)\end{array}$ \\
\hline Borr. country realized volatility $l, g$ & $\begin{array}{c}-0.007 \\
(-0.880)\end{array}$ & $\begin{array}{c}-0.008 \\
(-0.877)\end{array}$ & $\begin{array}{l}-0.012 \\
(-0.944)\end{array}$ & $\begin{array}{l}-0.010 \\
(-0.795)\end{array}$ \\
\hline Borr. country RGDP growth Re, $_{l, p}$ pct & $\begin{array}{c}0.003 \\
(0.259)\end{array}$ & $\begin{array}{c}0.005 \\
(0.433)\end{array}$ & $\begin{array}{c}0.011 \\
(0.800)\end{array}$ & $\begin{array}{c}0.010 \\
(0.725)\end{array}$ \\
\hline Borr. country short-term rate $l, g$, pct & $\begin{array}{l}-0.035^{*} \\
(-1.755)\end{array}$ & $\begin{array}{c}-0.028 \\
(-1.356)\end{array}$ & $\begin{array}{c}-0.001 \\
(-0.079)\end{array}$ & $\begin{array}{c}-0.002 \\
(-0.145)\end{array}$ \\
\hline Borr. country 10-year sovereign rate $_{l, g}$, pct & $\begin{array}{c}0.051^{* *} \\
(2.769)\end{array}$ & $\begin{array}{c}0.047^{* *} \\
(2.194)\end{array}$ & $\begin{array}{c}-0.001 \\
(-0.039)\end{array}$ & $\begin{array}{c}-0.002 \\
(-0.139)\end{array}$ \\
\hline Lender fixed effects & $\mathrm{Y}$ & $\mathrm{Y}$ & $\mathrm{Y}$ & $\mathrm{Y}$ \\
\hline Portfolio region fixed effects & $\mathrm{Y}$ & $\mathrm{Y}$ & $\mathrm{Y}$ & $\mathrm{Y}$ \\
\hline Num. of observ. & 2094 & 1680 & 1481 & 1282 \\
\hline R-sq. adj. & 0.33 & 0.30 & 0.27 & 0.25 \\
\hline R-sq. within. & 0.09 & 0.09 & 0.08 & 0.08 \\
\hline RMSE & 0.58 & 0.59 & 0.64 & 0.64 \\
\hline $\begin{array}{l}\text { statistics in parentheses. }{ }^{*} p<.1,{ }^{* *} p<. \\
\text { Note. The dependent variable is the simple a } \\
g \text { of lender } l \text {. The variable "Low capitalizati } \\
\text { bank and a nonbank lender) is headquartere } \\
\text { capital ratio is in the bottom } 25 \text { th percentile } \\
\text { and }(2) \text { ) or if lender } l \text { (a bank) has a equity- } \\
\text { of the distribution of such bank ratios (in co } \\
\text { in columns (1) and (2) and } 120 \text { to } 140 \text { in co } \\
\text { lender. }\end{array}$ & $\begin{array}{l}5,{ }^{* * *} p<. \\
\text { erage of pr } \\
\mathrm{n}_{l, t} \text { " is a d } \\
\text { in a count } \\
\text { f the distril } \\
\text { ver-assets } \\
\text { imns }(3) \text { an } \\
\text { umns }(3) \text { a }\end{array}$ & $\begin{array}{l}\text { jected EDFs for } \\
\text { mmy that is equ } \\
y \text { in which the } \\
\text { ution of such cor } \\
\text { atio which is in } \\
\text { (4)). The num } \\
d(4) \text {. Errors ar }\end{array}$ & $\begin{array}{l}\text { orrowers } \\
\text { to } 1 \text { if le } \\
\text { gregate } \mathrm{T} \\
\text { try ratios } \\
\text { er of lend } \\
\text { clustered }\end{array}$ & $\begin{array}{l}\text { loan portfolio } \\
\text { der } l \text { (either a } \\
\text { er } 1 \text { risk-based } \\
\text { in columns }(1) \\
\text { sth percentile } \\
\text { s is } 230 \text { to } 250 \\
y \text { quarter and }\end{array}$ \\
\hline
\end{tabular}

